Canadian

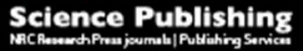

Botany

Botanique

\title{
Taxonomic and cytogenetic studies in Opuntia ser. Armatae (Cactaceae)
}

\begin{tabular}{|r|l|}
\hline Journal: & Botany \\
\hline Manuscript ID & cjb-2016-0048.R2 \\
\hline Manuscript Type: & Article \\
\hline Date Submitted by the Author: & $17-$ Aug-2016 \\
\hline Complete List of Authors: & $\begin{array}{l}\text { Las Peñas, Maria; MBIV, Instituto Multidisciplinario de Biología Vegetal, } \\
\text { Universidad Nacional de Córdoba-CONICET } \\
\text { Oakley, Luis; Cátedra de Botánica, Facultad de Cs. Agrarias, Universidad } \\
\text { Nacional de Rosario, Campo Experimental José Villarino, C.C. 14 } \\
\text { Moreno, Natalia; IMBIV, Instituto Multidisciplinario de Biología Vegetal, } \\
\text { Universidad Nacional de Córdoba-CONICET } \\
\text { Bernardello, Gabriel; IMBIV, Instituto Multidisciplinario de Biología Vegetal, } \\
\text { Universidad Nacional de Córdoba-CONICET }\end{array}$ \\
\hline Keyword: & \begin{tabular}{l} 
heterochromatin, new combinations, new varieties, synonymy, FISH \\
\hline
\end{tabular} \\
\hline
\end{tabular}




\section{Taxonomic and cytogenetic studies in Opuntia ser. Armatae (Cactaceae)}

M. Laura Las Peñas, Luis Oakley, Natalia C. Moreno, and Gabriel Bernardello

M. Laura Las Peñas, Natalia C. Moreno, and Gabriel Bernardello. Instituto Multidisciplinario de Biología Vegetal (IMBIV), Universidad Nacional de CórdobaCONICET, C. C. 495, 5000 Córdoba, Argentina.

Luis Oakley. Cátedra de Botánica, Facultad de Cs. Agrarias, Universidad Nacional de Rosario, Campo Experimental José Villarino, C.C. 14, 2125 Zavalla, Santa Fe, Argentina.

Corresponding autor: M. Laura Las Peñas, Instituto Multidisciplinario de Biología Vegetal, C. C. 495, 5000 Córdoba, Argentina, +54 351 4332104, e-mail: laulaspenas@yahoo.com.ar. 
Abstract. Opuntia series Armatae is evaluated considering morphological (vegetative, floral and carpological) and cytogenetical (diploid number, presence of heterochromatin and physical localization of ribosomal genes) features to shed light on their systematics and evolution. Three complexes (named O. elata, O. megapotamica and O. monacantha) are proposed to accommodate seven species according to the tepal, fruit, stigma and seed aril traits. Additional systematic conclusions include: 1. O. stenarthra, O. assumptionis, $O$. cognata and $O$. subsphaerocarpa are synonyms; 2. O. elata is a variable species with two varieties: var. cardiosperma and var. obovata; 3. O. rioplatense is a synonym of O. elata var. obovata and 4. O. megapotamica is a polymorphic species with two varieties (one newly described and a new combination). All species had small similar-sized symmetrical chromosomes and were tetraploid $(2 \mathrm{n}=44)$, except for a population of $O$. arechavaletae and O. monacantha $(2 \mathrm{n}=22)$. All showed one or two pairs with $\mathrm{CMA}^{+} / \mathrm{DAPI} \mathrm{NOR}$ associated bands. The 18-5.8-26S rDNA loci seem to coincide with CMA+/DAPI'/NORs blocks. The number of $5 \mathrm{~S}$ signals detected was proportional to the ploidy level of the species. A combination of cytogenetic and morphological features helped to differentiate the complexes, species, and varieties of Opuntia ser. Armatae.

Key words: FISH, heterochromatin, South America, synonymy, new combinations, new varieties. 


\section{Introduction}

Opuntia Mill. (subfam. Opuntioideae, tribe Opuntieae) is one of the largest genera of cacti (with ca. 150 spp.;Stuppy 2002) and it has a widespread distribution from northern Patagonia to southern Canada (Kiesling 1975; Barthlott and Hunt 1993; Hunt et al. 2006). Its species, widely known as prickly-pear, tuna or nopal, present a combination of typical traits: flat rounded articulated stem segments (cladodes or platyclades), very small early caducous leaves, large smooth fixed spines and areoles with glochids, showy rotaceous flowers with inferior ovaries surrounded by the pericarpels, plurilobed stigma, stamens with thigmonasty, reticulate semitectate pollen and seeds covered by a sclerified funicular aril (Buxbaum 1953; Kiesling 1984a; Anderson 2001; Stuppy 2002; Hunt et al. 2006). Opuntia systematics is complex, mainly because the species have high phenotypic plasticity and vegetative reproduction (by apomixis and stem or sterile fruits forming adventitious roots) as well as a high degree of hybridization (Griffith 2001; Reyes-Agüero et al. 2006; Kiesling et al. 2011). As a consequence, many populations are clonal (Kiesling et al. 2011).

One of the most controversial infrageneric groups is $O$. series Armatae K. Schum. because of the difficulties regarding the interpretation and identification of its entities (Leuenberger 2002). This series includes ca. seven erect shrubby species native to southern South America (Bolivia, Paraguay Brazil, Argentina, and Uruguay). Its members are mainly erect, highly branched shrubs, rarely exceeding $2 \mathrm{~m}$ in height and having flowers with yellow, orange, or yellow-orange tepals. Leuenberger (2002) and Font (2014) reviewedthis taxonomic complex adopting different criteria for its species delimitation and naming. Font (2014) reported useful reproductive traits to delimit its taxa, but disregarded seed characters that are of taxonomic importance in dicotyledons (Corner 1976) and, particularly, in the Opuntioideae (Engleman 1960; Stuppy 2002). 
Cytogenetic studies have proved to be significant in understanding the diversification of plant families as a whole and of the Cactaceae in particular. In Opuntioideae, most cytogenetic information available refers to the chromosome number and karyotypes from North American taxa (e.g., Bandyopadhyay and Sharma 2000; Palomino and Heras 2001), but these data are scarce for South American species (e.g., Las Peñas et al. 2009; Realini et al. 2014; Castro et al. 2016). As in most of the Cactaceae, its base number is $\mathrm{x}=11$ and polyploidy has been important in its evolution, with ca. $65 \%$ of the examined species being tetra-, hexa-oroctoploids (Remski 1954; Palomino et al. 1988; Cota and Philbrick 1994; Pinkava 2002; Christian et al. 2006; Majure et al. 2012c; Goldblatt and Johnson 2013).

Chromosome banding and fluorescence in situ hybridization (FISH) have rarely been applied to Cactaceae and Opuntioideae (Las Peñas et al. 2008, 2009; Realini et al. 2014; Moreno et al. 2015a, $b$; Castro et al. 2016). Both techniques have provided valuable tools for studies on genome organization and evolution in plants (e.g., Sumner 1990; Jiang and Gill 2006; Raskina et al. 2008). The physical mapping of tandem repeat genes (rDNA) with FISH resulted in helpful markers for karyotype comparisons for evaluating relationships and divergence among species and populations (Jiang and Gill 2006; Raskina et al. 2008). The 5S and 18-5.8-26S rDNA genes, in particular, have been extensively used to establish possible chromosomal homeologies (e.g., Moscone et al. 1999; Adams et al. 2000; Taketa et al. 2005).

With this background in mind, in this study the species of Opuntia ser. Armatae have been morphologically and cytogenetically analyzed to shed light on their systematics and evolution. The specific objectives were: a) to analyze their vegetative, floral and carpological features, b) to determine the diploid chromosome number, presence of heterochromatin, and physical localization of ribosomal genes, and c) to define the species complexes, species and varieties using the previous data. 


\section{Materials and Methods}

Accessions from the following Herbaria have been studied (listed in appendix A1): BA, BAB, BACP, BBB, CORD, CTES, FCQ, LIL, PY, SF, SI, and UNR (abbreviated after Thiers, continuously updated). In addition, specimen images available on the web (from the Herbaria K, G, and P, and from JSTOR) were used. The available herbarium specimens were annotated with their geographical distribution, examined for basic morphology and used for delimiting the species. Field observations of the vegetative and reproductive characters were carried out on 23 native populations from 1999 to 2015 in Argentina and Paraguay (Table 1, Fig. 1). Features used by previous botanists that worked with the Armatae series (Schumann 1899; Leuenberger 2002; Machado 2008; Font 2014) were compared in five fresh specimens of each population: degree of hairiness of the seed aril, color of stigmatic lobes and of the fruit inner pulp, development and relative position of the locule, and the morphology of the stem segments.

Opuntia ser. Armatae species and collection data of the 23 populations cytogenetically studied are included in Table 1 and Fig. 1 that cover the distribution range of the species. For metaphase preparations, adventitious roots from potted plants were pretreated with $2 \mathrm{mM} 8$ hydroxyquinoline for $24 \mathrm{~h}$ at $4^{\circ} \mathrm{C}$ and fixed in 3:1 ethanol:acetic acid. Root tips were twice washed in distilled water (10 min each), digested with a solution of $2 \%$ cellulose (Sigma Aldrich) and 20\% pectinase (from Aspergillus niger; SigmaAldrich) for $45 \mathrm{~min}$ at $37^{\circ} \mathrm{C}$ and squashed in a drop of $45 \%$ acetic acid (Schwarzacher et al. 1980). After coverslip removal in liquid nitrogen, the slides were stored at $-20^{\circ} \mathrm{C}$. Ten metaphases of five individuals per population were photographed and the photographs were used to measure the following features for each chromosome pair: s (short arm), 1 (long arm), and c (total chromosome length); the length of the satellite was added to the respective chromosome arm. The arm ratio $(r=1 / s)$ was then calculated and used to classify the chromosomes as recognized by Levan et 
al. (1964). In addition, the mean chromosome length (C) and mean total haploid chromosome length (TLH) of the karyotype based on the mean chromosome length (TL) were calculated. Idiograms were based on mean values. Chromosomes were first arranged into groups according to their increasing arm ratio and then according to the decreasing length within each group.

Slides for CMA/DAPI banding were first stained with a drop of $0.5 \mathrm{mg} \mathrm{mL1}$ chromomycin $\mathrm{A}_{3}$ (CMA) for 90 min, then with $2 \mu \mathrm{g}$ mL1 4'-6-diamidino-2-phenylindole (DAPI) for 30 min (both stains from Sigma-Aldrich), and mounted in McIlvaine's buffer:glycerol (1:1) (Schweizer 1976; Schweizer and Ambros 1994). Using five metaphases of five individuals per species, the relative lengths of short and long chromosome arms (data not shown) and bands were calculated (considering haploid karyotype length $=100 \%$ ). The amount of heterochromatin was expressed as a percentage of the total length of the haploid karyotype.

The FISH protocol was developed after Schwarzacher and Heslop-Harrison (2000). To identify the rDNA 18S-5.8S-26S loci, the pTa71 probe was used (Gerlach and Bedbrook 1979), labelled with biotin-14-dUTP by nick translation (Bionick, Invitrogen) and subsequently detected with avidin-fluorescein isothiocyanate (Sigma). For analysis of the 5S rDNA loci, a specific probe was obtained from the genome of Pereskia aculeata Mill. by PCR (Las Peñas et al. 2011). These fragments were labelled with digoxigenin-11-dUTP (DIG Nick translation mix; Roche) and detected with anti-DIG-rhodamine (Roche). Slides were mounted with antifade Vectashield (Vector Laboratories) containing DAPI.

Principal Component analyses (PCA) were used to reveal similarities among the studied taxa [considered as operational taxonomic units (OTUs)]. For this purpose, the following independent karyotype variables previously obtained, which do not implicate chromosome homologies, were employed: mean total haploid chromosome length (TLH), 
heterochromatin amount expressed as percentage of the karyotype length $(\% \mathrm{Ht})$, number of $\mathrm{CMA}^{+} / \mathrm{DAPINOR}$ associated signals, position of $\mathrm{CMA}^{+} / \mathrm{DAPI}^{-}$bands, number of $18-5.8-26 \mathrm{~S}$ and 5S loci (appendix A2 and A3). In addition, the following independent morphological variables were analyzed from fresh specimens: fruit shape, aril pubescence, flower bud apex, color of fruit inner pulp, and stigma lobe color (appendix A2 and A3). INFOSTAT version1.1 (Di Rienzo et al. 2012) was used in all the analyses involving numerical data.

\section{Results}

\section{Taxonomy}

The two-dimensional plot obtained from the PCA using the morphological features is included in Fig. 2. The variation in the different variables throughout the ordination space is given by the direction and length of the eigenvectors, represented as lines. The first principal component (CP1) accounts for $58.1 \%$ of the total variation of the group (the differentiating traits being fruit pulp color and shape, aril pubescence, and the color of the stigmatic lobes), and the second (CP2) for $18.8 \%$. The six populations of $O$. elata and the four populations of O. stenarthra were grouped towards the right-hand side of the Euclidean space with O. elata on the upper side and $O$. stenarthra on the lower side. On the other hand, the nine populations of O. megapotamica, O. bonaerensis, and O. penicilligera were clustered on the left-hand side of the plot. The central part of the plot is occupied by $O$. arechavaletae and O. monacantha.

According to these results, the analysis of herbarium accessions (appendix A1), and living populations, three defined complexes are proposed to accommodate the seven recognized species of Opuntia ser. Armatae, using the criteria of Majure et al. (2012a) for $O$. humifusa (Raf.) Raf.; the complexes are named after their oldest species. The main morphological features utilized to characterize them are related to tepal, fruit, stigma, and 
seed aril (see identification key below). A description of each complex and the species that composed them follow.

A. Opuntia elata complex: Erect shrubs or subshrubs, sometimes prostrate. Yellow, yellow-orange or orange flowers. Spatulate to cordate tepals. Obconic, obovate, or obpyriform fruits with well-developed locules. Greenish fruit pulp. Creamy stigmatic lobes. Glabrous or pubescent arils.

This taxonomic complex comprising $O$. elata and $O$. stenarthra. Opuntia elata has a widespread distribution and shows variability, being considered as having two varieties (see Discussion). At the same time, the identity and geographical distribution of $O$. stenarthra is elucidated and three new synonyms are proposed (see Discussion).

B. Opuntia megapotamica complex: Erect shrubs or prostrate subshrubs. Orange or yellow-orange flowers. Spatulate, trasovate to cordate tepals. Obconic, obpyriform or elliptical fruits with well-developed locules. Red-wine colored fruit pulp. Greenish stigmatic lobes. Glabrous aril.

This taxonomic complex is composed of $O$. megapotamica, $O$. bonaerensis and $O$. penicilligera. Opuntia megapotamica is a variable species considered as including two varieties (see Discussion). On the other hand, O. bonaerensis and O. penicilligera are well known and defined species; their descriptions and additional information are available in Font (2014) and in Leuenberger and Arroyo-Leuenberger (2014).

C. Opuntia monacantha complex. Erect shrubs or small trees with a definite trunk. Yellow flowers. Lanceolate, sometimes spatulate tepals. Turbinate, obovoid or 
obclaviform fruits. Greenish fruit pulp. Creamy or greenish stigmatic lobes. Glabrous arils.

This taxonomic complex includes $O$. monacantha and $O$. arechavaletae. Both species are well defined and their descriptions and additional information can be seen in Taylor and Zappi (2004) and in Font (2014).

\section{Cytogenetics}

All species were found to be tetraploid $(2 \mathrm{n}=44)$, except for the diploid O. monacantha and one population of $O$. arechavaletae $(2 \mathrm{n}=22)$. The species exhibited small similar-sized symmetrical chromosomes. The mean chromosome length for all taxa was $2.37 \mu \mathrm{m}$ (range

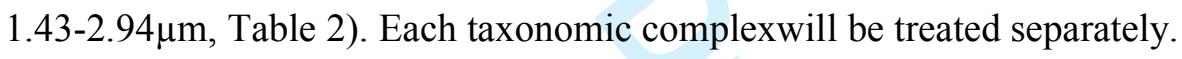

Opuntia monacantha complex. Both populations of $O$. monacantha studied were diploid (Fig. 3 A). The average heterochromatin percentage was 3.02\% (Table 2). All populations showed one pair with $\mathrm{CMA}^{+}$/DAPI NOR associated bands (Fig. 3 A-B). Two signals for the $45 \mathrm{~S}$ and $5 \mathrm{~S}$ genes were detected with FISH (Fig.5 A). In addition, two populations of O.arechavaletae were analyzed: one was diploid (Santa Fe) and the other tetraploid (Entre Rios). The diploid cytotype had two chromosome pairs with bands: one with $\mathrm{CMA}^{+} / \mathrm{DAPI}^{-} \mathrm{NOR}$ associated bands and the other with a centromeric band (Fig. 3 C-D), whereas the tetraploid showed four pairs with the same type of bands (Fig.3 E-F). Interestingly, the heterochromatin percentage was higher in the diploid than in the tetraploid (Table 2). Regarding the visualization of rDNA genes using FISH, the diploid cytotype had one chromosome pair with 45S signals and another pair with 5S, whereas the tetraploid cytotype doubled them (Fig. 5 B-C, 6). 
Opuntia elata complex. The twelve populations analyzed in this complex were tetraploid $(2 n=44)$. The average heterochromatin percentage was $3.00 \%$ (Table 2$)$.

Concerning the three varieties of $O$. elata, the heterochromatin percentage ranged from 1.54 to $4.30 \%$ (Table 2 ). These varieties showed variability in their banding pattern. Both var. cardiosperma and var. elata possessed a chromosome pair with one $\mathrm{CMA}^{+} / \mathrm{DAPI}$ NOR associated band and a single chromosome with a terminal $\mathrm{CMA}^{+} / \mathrm{DAPI}$ band, whereas in var. obovata there were two pairs with $\mathrm{CMA}^{+} / \mathrm{DAPI}^{-} \mathrm{NOR}$ associated bands and a single chromosome with one centromeric $\mathrm{CMA}^{+}$/DAPI band (Fig. 3 G-L). On the other hand, all varieties showed the same pattern of rDNA genes: one pair with 45S signals and two pairs with 5S signals (Fig. 5 D-F). In addition, in var. elata (Entre Ríos population) and var. obovata the $45 \mathrm{~S}$ probe hybridized in a single chromosome in the centromeric region (Fig. 6). All populations of $O$. stenarthra showed one chromosome pair with $\mathrm{CMA}^{+} / \mathrm{DAPI}$ NOR associated bands and another pair with terminal $\mathrm{CMA}^{+} / \mathrm{DAPI}$ bands (Fig. 4A-B). Two signals for the $45 \mathrm{~S}$ and four for the $5 \mathrm{~S}$ genes were detected with FISH (Fig. $5 \mathrm{G}, 6$ ).

Opuntia megapotamica complex. All taxa studied were tetraploid $(2 \mathrm{n}=44)$. The overall heterochromatin percentage varied from 1.83 to $5.87 \%$ (Table 2). Two banding patterns were observed: O.bonaerensis, O.megapotamica var. megapotamica and O. penicilligera had one chromosome pair with $\mathrm{CMA}^{+} / \mathrm{DAPI}^{-} \mathrm{NOR}$ associated bands, together with all centromeric or terminal $\mathrm{CMA}^{+} / \mathrm{DAPI}^{-}$bands of different sizes (Fig. 4 C-L). Opuntia megapotamica var. salagria and var. chadihuensis showed two chromosome pairs with $\mathrm{CMA}^{+} / \mathrm{DAPI}$ NOR associated bands (Fig. 6). Regarding the rDNA genes, all the taxa of the complex showed two pairs with $45 \mathrm{~S}$ signals as well as two pairs with $5 \mathrm{~S}$ signals(Fig. $5 \mathrm{H}-\mathrm{J}$ ); on the other hand, $O$. penicilligera only had one chromosome pair with $45 \mathrm{~S}$ signals (Fig. $5 \mathrm{~L}$ ). In addition, $O$. megapotamica var. salagria and $O$. penicilligera showed one centromeric $45 \mathrm{~S}$ signal on a single chromosome of the pair (Fig. 6). 
The two-dimensional plot obtained from the PCA with cytological data is included in Fig. 7. The variation in the different variables throughout the ordination space is given by the direction and length of the eigenvectors, represented as arrows. The first principal component (CP1) accounts for the $35.2 \%$ of the total variation of the group (being TLH, heterochromatin percentage, number of $\mathrm{CMA}^{+} / \mathrm{DAPI} \mathrm{NOR}$ associated bands, and presence of $\mathrm{CMA}^{+} / \mathrm{DAPI}^{-}$ bands the differentiating traits) and the second (CP2) for the $27.5 \%$ (being chromosome number, and number of $45 \mathrm{~S}$ and $5 \mathrm{~S}$ genes the discriminating features). The chromosome number separated the tetraploids, located in the lower side of the plot, from the diploids. There is a considerable mixing among the complexes, most species being grouped towards the upper side of the Euclidean space. Most O. stenarthra samples were separated towards the extreme right-hand side of the plot whereas the seven samples of O. megapotamica were clustered on the left-hand side of the plot.

\section{Discussion}

\section{Cytogenetics}

The cytogenetic data obtained mostly agreed with previous reports for these taxa (Majure et al. 2012c; Realini et al. 2014) on members from different populations. Opuntia elata var. obovata and O. megapotamica var. chadihuensis were studied for the first time, whereas for O. monacantha and O. arechavaletae new cytotypes are reported (Table 2). Our results confirmed that the basic chromosome number for Opuntioideae is $\mathrm{x}=11$ (e.g., Pinkava 2002; Goldblatt and Johnson 2013).

Most chromosome counts in ser. Armatae came out as tetraploid. There are some diploid species as well (Realini et al. 2014), including O. monacantha, and a diploid population of $O$. arechavaletae, both reported here for the first time. It is suggested that 
polyploidy has been an important evolutionary mechanism in the Cactaceae (Cota and Wallace 1995; Las Peñas et al. 2009); in particular it seems to have played a key role in the Opuntioideae, in which $64 \%$ of the available counts were tetraploids and $13.4 \%$ of the taxa included both tetraploid and diploid cytotypes (Pinkava 2002; Powell and Weedin 2001;Das and Mohanty 2006; Majure et al. 2012b, c; Goldblatt and Johnson 2013; our data). However, there no additional data for understanding the biological role of these cytotypes.

All Opuntia species studied had small chromosomes and symmetrical karyotypes mostly composed of $m$ and $s m$ chromosomes, as is frequent in basal grade and crown clades members of the Cactaceae in general (Echinocereus: Cota and Wallace 1995; Echinopsis: Das and Mohanty 2006; Mammillaria: Christian et al. 2006; Pyrrhocactus: Las Peñas et al. 2008; Setiechinopsis: Las Peñas et al. 2011; Pereskia, Maihuenia: Las Peñas et al. 2014; Lepismium: Moreno et al. 2015a; Castro et al. 2016) and the Opuntioideae in particular (e.g., Bandyopadhyay and Sharma 2000; Palomino and Heras 2001; Las Peñas et al. 2009; Realini et al.2014; Castro et al. 2016). Karyotypic orthoselection might have occurred, preserving relatively similar complements in Opuntioideae because they seem to be more stable, a condition also reported in other Cactaceae groups (e.g., Cota and Wallace 1995; Las Peñas et al. 2008, 2009).

In most the examined angiosperm genera, the CMA/DAPI banding technique showed that the number of bands and heterochromatin amount varied, although the pattern was fairly well conserved (e.g., Guerra 2000; Stiefkens et al. 2010; Moreno et al. 2015a). In Opuntia, there is a previous report that includes some members of ser. Armatae (Realini et al. 2014). Some of our results differ from theirs (see Table 2 in Realini et al. 2014), as detailed in our Table 2, probably due to intraspecific variation.

Fluorochrome banding suggests the homeology of NOR-bearing \#1 pair in Opuntia ser. Armatae. Although more data are required, it seems to be conserved in the Cactaceae (Las 
Peñas et al., 2008, 2009, 2011, 2014; Moreno et al. 2015a, b; Castro et al. 2016). In some species (O. elata var. cardiosperma, O. stenarthra, O. megapotamica var. chadihuensis), the heteromorphic $\mathrm{CMA}^{+} / \mathrm{DAPI}^{-} \mathrm{NOR}$ associated bands are probably due to an increment in the number of CG rich sequences. Both the position and number of bands are valuable tools for differentiating the species studied (Fig. 6). Our data and previous reports (Las Peñas et al. 2008, 2009, 2011; Moreno et al. 2015a, $b$; Castro et al. 2016) suggest an important variation in the CMA+ bands in the different Cactaceae subfamilies. No bands were detected in Pereskioideae and Maihuenioideae, whereas in the few Cactoideae and Opuntioideae examined there are bands in different positions and the numbers of bands are generally characteristic for each genus (Las Peñas et al. 2008, 2009, 2011, 2014; Moreno et al. 2015a, b). Interestingly, the tetraploid cytotype of $O$. arechavaletae had a lower heterochromatin percentage than the diploid. Polyploidy is frequently associated with changes in the genome structure, which leads to the loss or gain of DNA sequences (Leitch and Leitch 2008), as could have happened in this case. In several families of angiosperms (e.g., Calyceraceae, Dipsacaceae, Solanaceae) the karyotype length (and consequently, chromosome size) and percentage of heterochromatic bands are correlated (Pringle and Murray 1993; Benko-Iseppon and Morawetz 2000; Chiarini et al. 2013). In Cactaceae, this correlation has so far been detected in species of Pyrrocactus together with an increased in the asymmetry of karyotypes (Las Peñas et al. 2008).

In angiosperms, $18 \mathrm{~S}-5.8 \mathrm{~S}-26 \mathrm{~S}$ rDNA sites located in terminal regions of short chromosome arms are frequent (Roa and Guerra 2012; García et al. 2013). This locus seems to coincide with a $\mathrm{CMA}^{+} / \mathrm{DAPI}^{-} \mathrm{NOR}-$ associated band in \#1 pair in the scarce Cactaceae species examined so far (Las Peñas et al.2009, 2011, 2014; Moreno et al. 2015a, $b$; Castro et al. 2016). Few data on the 5S rDNA loci localization are available in the Cactaceae (Las Peñas et al. 2011, 2014; Moreno et al. 2015a, b; Castro et al. 2016), ours being the first report 
on Opuntia. The number of 5S rDNA signals in all the tetraploid Opuntia was four and in the diploid population of $O$. arechavaletae and $O$. monacantha, two; thus, it would indicate the ploidy level. In O. arechavaletae, the tetraploid cytotype might be an autopolyploid, because it has duplicated the number and position of the $18 \mathrm{~S}-5.8 \mathrm{~S}-26 \mathrm{~S}$ and $5 \mathrm{~S}$ genes and $\mathrm{CMA}^{+} / \mathrm{DAPI}^{-}$bands.

Cytogenetic features did not help in differentiating between the complexes of Opuntia ser. Armatae. Our data suggest that the series may be characterized by having interstitial and terminal $\mathrm{CMA}+$ heterochromatin in at least one chromosome pair, a banding pattern coincident with the few Opuntia studied so far (Realini et al. 2014; Castro et al. 2016). The occurrence of $\mathrm{CG}$ rich heterochromatin in unrelated genera of the Opuntioideae and Cactoideae (Las Peñas et al. 2008, 2011; Moreno et al. 2015a, b) suggests its independent origin. The number of $5 \mathrm{~S}$ signals was indicative of the ploidy level of the species (Lichtenzveig et al. 2000; LasPeñas et al. 2014).

The few Opuntioideae phylogenies published (Griffith and Porter 2009; Majure et al. 2012b; Ritz et al. 2012; Bárcenas 2015; Realini et al. 2015) proposed that genera differentiation in this subfamily is not completely resolved. It is a taxonomically difficult group with high degrees of polyploidy and a high incidence of interspecific hybridization showing intricate patterns of variation (Pinkava 2002; Negrón-Ortiz 2007; Majure et al. 2012a, $b$; Hernández et al. 2014). Additional data on the phylogeny of South American taxa are needed in order to understand their evolution.

\section{Taxonomic treatment}

In Table 3, an exhaustive comparative list of ser. Armatae taxa in both previous revisions and this work is provided. The circumscription of the seven recognized species, their 
synonyms and doubtful taxa are specified. An identification key and the main taxonomic novelties regarding changes in the status of the taxa are included below.

\section{Identification key}

1a. Erect shrubs or subshrubs. Flowers yellow-orange or orange (rarely yellow) with

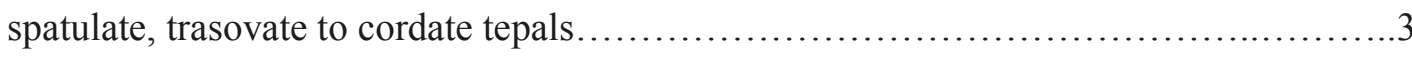

1b. Erect shrubs or small trees with definite trunk. Flowers yellow with lanceolate -sometimes spatulate- tepals (O. monacantha complex)

2a. Bright yellow tepals. Creamy stigmatic lobes. Narrowly turbinate to obovoid fruits, with well-developed locules. O. monacantha

2b. Pale yellow tepals. Greenish stigmatic lobes. Slender obclaviform fruits with a small locule at their apex............................................. arechavaletae

3a. Creamy stigmatic lobes. Fruits with greenish pulp. Seeds with glabrous or pubescent arils (O. elata complex). .4

3b. Greenish stigmatic lobes. Fruits with red-vine colored pulp. Seeds with glabrous arils $(O$. megapotamica complex).....

4a. Erect shrubs. Generally glabrous arils. .5

4b. Erect shrubs or subshrubs, sometimes prostrate. Pubescent arils. O. sternarthra

5a. Seeds with completely glabrous arils

5b. Seeds with arils, only pubescent on the lateral sides (glabrous in the funicular ring). Obtuse floral bud apex O. elata var. cardiosperma 
6a. Floral bud apex, obtuse or flat O. elata var. elata

6b. Floral bud apex, acute O. elata var. obovata

7a. Erect shrubs. .8

7b. Prostrate subshrubs. Obovoid stem segments. Areoles with numerous conspicuous ferruginous glochids. O. penicilligera

8a. Areoles with conspicuous reddish-brown groups of glochids. Mainly suborbicular stem segments.

8b. Areoles with scarce short glochids. Elliptic or spatulate stem segments. O. bonaerensis

9a. Orbicular or suborbicular -sometimes subspatulate- stem segments...

9b. Elliptic-obovate or subspatulate stem segments, with 15-20 areoles in each side. Mostly unarmed. O. megapotamica var. chadihuensis

10a.Green stem segments up to $2.5 \mathrm{~cm}$ in thickness, with $15-30$ areoles on each side. Areoles with 2 (3) rigid spines, up to $10 \mathrm{~cm}$ long. Pericarpel unarmed

O. megapotamica var. megapotamica

10b.Glaucous stem segments, $1-1.5 \mathrm{~cm}$ in thickness, with 35-40 areoles on each side. Areoles with 2(3) slender spines, up to $4 \mathrm{~cm}$ long. Pericarpel with small spines on the upper margin. O. megapotamica var. salagria

\section{Infraspecific variation of Opuntia elata}


Opuntia elata has a wide geographical distribution and a high degree of variability in stem segment size, number and length of spines, fruit shape and aril pubescence. The same applies to the apex of the flower buds (lightly flat, truncated, or obtuse). In some populations, the flower bud apex is acute, a character used to define $O$. rioplatense; however, other traits that distinguish this species, such as "areoles on low protuberances and large, dark glossy green" and "receptacle with redish glochids above" (Font 2014), were found in populations with other bud shapes. Thus, O. elata is regarded as a variable species with two varieties, in addition to the typical variety (see the identification key for diagnostic differences) that were separated in the PCA plot (Fig. 2).

Opuntia elata Salm-Dyck var. elata, Hort. Dyck. 361. 1834. TYPE: Uruguay, Salto, 7 March 1917, Shafer 120. NEOTYPE: US, designated by Leuenberger 2002: 423. ISOTYPE: K. Fig. 8 A-C

Opuntia canterae Arechav. Fl. Uruguaya 2: 278. 1905 (1902). TYPE: Lám. LX in Osten (1941). NEOTYPE: designated here.

Opuntia pyrrhantha F. Ritter ex P. J. Braun \& Esteves., Succulenta 74: 133. 1995.

Platyopuntia pyrrhantha F. Ritter, Kakteen Südam. 2: 498. 1980. nom. illeg. TYPE: Bolivia, Tarija, Taringuiti, 1963, Ritter 1166. HOLOTYPE: U. ISOTYPES: ZSS, SGO DESCRIPTION: Erect shrubs up to 2.5 (3) m tall, branched. Stem segments obovate, oblongobovate, sometimes subspatulate, 8-25 (30) cm long, 5-10 (13) cm wide and 1.5-2.5 $\mathrm{cm}$ thick, dark green; areoles (10) 15-20 (30) on each side, circular or elliptic, 3-5 mm diam., with white tomentum and 0-2 (3) subulate to acicular whitish spines (1) 4-5 (8) cm length. Flower buds with an obtuse or flat apex. Flowers with orange to yellow-orange tepals, 6-7 (8) $\mathrm{cm}$ diam. when open. Pericarpel (3) 6 (7.5) cm length, sometimes with purple stripes below the areoles. 
Style obclaviform, creamy, stigma with 6-7 creamy lobes. Fruits obovate to obpyriform, 5-7 cm long x 3-4 cm diam., umbilicate, red or purple-violet without, with greenish inner pulp. Seeds with glabrous arils or with short adpressed hairs, lenticular, (3.5) 5-6 mm diam. x 1.5-3 mm thick.

DISTRIBUTION AND HABITAT: NE Argentina (Buenos Aires, Chaco, Corrientes, Entre Rios, Formosa, Misiones and Santa Fe), SE Bolivia (Tarija), Paraguay (Boquerón, Central, Cordillera and Presidente Hayes), S Brazil (Rio Grande do Sul) and Uruguay. It grows at the edge of dry forests, savannas, canyons and valleys, as well as in anthropogenic areas (railroads, fences edges), on loam or clay soils.

Opuntia elata Salm-Dyck var.cardiosperma (K. Schum.) R. Kiesling, Fl. Ilustr. Entre Ríos4 b: 412. 2005. Fig. $8 \mathrm{D}$

BASIONYM: Opuntia cardiosperma K, Schum.Monatsschr. Kakteenk. 9: 150. 1899. TYPE: Paraguay, near Recoleta, Asunción, 3 March 1899, Anisits 64. LECTOTYPE: B designated by Leuenberger 2001: 174

Opuntia mieckleyi K. Schum.,Blüh. Kakteen 1: t. 44. 1903. TYPE: Fig. 44 in Schumann (1903: t. 44). LECTOTYPE: designated by Crook and Mottram (2000: 128)

Opuntia chakensis Speg. Anales Mus. Nac. Buenos Aires ser. 3-4: 519. 1905.TYPE: Photograph in Spegazzini (1925: 95). LECTOTYPE: designated by Crook and Mottram (1996: 106). This species was described by Spegazzini (1905: 519-520) as with "seminibus glabris" and "seminibus...villo destitutis farctus", but when referring to it in a later paper (Spegazzini, 1925: 94-97), he indicated that it has densely pubescent seeds, being probable that in this publication he was examining material of O. stenarthra. 
Opuntia delaetiana (F.A.C. Weber) Vaupel, Blüh. Kakteen 3: t. 148. 1913.

BASIONYM:Opuntia elata Salm-Dyck var. delaetiana F.A.C. Weber ex Roland-Gosselin, Bull. Mus. Hist. Nat. (Paris) 10: 392. 1904. TYPE: Fig. 148 in Vaupel (1913: t. 148). NEOTYPE: designated by Leuenberger (2002: 421)

Opuntia limitata F. Ritter ex P. J. Braun \& Esteves, Succulenta 74: 133. 1995. Platyopuntia limitata F. Ritter, Kakteen Südam. 1: 245. 1979. nom. illeg. TYPE: Paraguay, Alto Paraguay, Puerto Casado, 1963, Ritter 1203. HOLOTYPE: U. ISOTYPE: SGO

It differs from the typical variety due to a noticeable pubescence on the lateral side of the seed (the funicular ring itself is glabrescent). Moreover, the stem segments are usually ellipticaloblong, with sinuous margins between the areoles, which have 1-2 brown short spines $0.5-3$ cm long.

DISTRIBUTION AND HABITAT: SE Bolivia (Chuquisaca, Santa Cruz and Tarija), W and Central Paraguay (Alto Paraguay, Boquerón, Central, Concepción, Cordillera, Neembucú, Presidente Hayes and San Pedro) and NE Argentina (Chaco, Corrientes, Formosa, Santa Fe and Santiago del Estero). It grows on the edges and within dry forests, on sandy-loam or alkaline clay soils.

Opuntia elata Salm-Dyck var. obovata E. Whalter, J. Cact. Succ. Soc. Amer. 1: 204. 1930. TYPE: Fig. 1 in Walther (1930: 203). LECTOTYPE: designated by Crook and Mottram (1996: 140). EPITYPE: designated here, Argentina, Santa Fe, Rosario, Zavalla, 3301'27.89''S/60'54'07.69''W, 10 November 2012, Galetti s. n. (UNR). Fig. 8 E-G

Opuntia rioplatense Font, Succ. P1. Res. 8: 85. 2014. Syn. nov. 
It differs from the typical variety because of its acute flower bud apex. Moreover, stem segments are usually obovate-oblong, as its epithet indicates.

DISTRIBUTION AND HABITAT: Central and E Argentina (Buenos Aires, Córdoba, Corrientes, Entre Ríos, La Pampa and Santa Fe) and W Uruguay. It grows in ravines, valleys and anthropogenic areas (railroads, fences edges), on loam or clay soils.

\section{Identity and geographical distribution of Opuntia stenarthra}

In the late nineteenth century, Schumann (1899) described three new Paraguayan species: O. stenarthra, O. assumptionis, and O. cardiosperma. For the first two, he indicated that their seeds are conspicuously hairy ("lanuginosis seminibus” for O. stenarthra and “dense seminibus villosis" for O. assumptionis). The other features he cited for distinguishing between them (stem segment shape, presence and type of thorns, flower color) have a high degree of continuous variation, as observed in many individuals from different populations of the Eastern Chaco of Argentina and Paraguay. Taking this into account together with the taxonomic significance of the seed characters and the analysis of both type specimens, we concluded that $O$. stenarthra and $O$. assumptionis are synonyms. According to Article 11.1 of ICNB, the valid name is $O$. stenarthra. Additionally, O. cardiosperma is here considered as a variety of $O$. elata (see above).

Leuenberger (2002) considered the possibility that O. stenarthra was actually a Brasiliopuntia A. Berger species, based on details of the original German diagnosis and Schumann's comments (1899: 150). Nevertheless, a comparison of its type specimen with sheets of Brasiliopuntia brasiliensis (Willd.) A. Berger and B. schulzii (A. Cast. \& Lelong) Backeb., showed that the stem segment features, and the shape and size of the spines, are different and that these taxa are not related. 
Eggli (2002) and Font (2014) pointed out that $O$. stenarthra might be akin to $O$. anacantha Speg. of ser. Aurantiacae Britton \& Rose, of which only O. anacantha var. retrorsa (Speg.) R. Kiesling grows in the Eastern Chaco (= O. retrorsa Speg.). Based on several differential traits, they are considered as different taxa. These features are: creeping or scandent subshrubs, high adventitious root production, lemon yellow tepals (pinkish orange when old), and cylindrical with an obconic base style for $O$. anacantha var. retrorsa and erect to semierect shrubs, few adventitious roots, yellow orange or orange tepals, and an obclaviform style for $O$. stenarthra.

Spegazzini (1925) described O. subsphaerocarpa from northern Argentina. As its main features and the type specimen matched those of $O$. stenarthra, it is treated as a new synonym. It was previously contemplated as a doubtful taxon (Kiesling 1984b, 1999; Leuenberger 2002) because of a contradiction between the last paragraph of its Spanish description and the original Latin diagnosis, as well as for the photographed specimen accompanying it.

Opuntia stenarthra K. Schum., Monatsschr. Kakteenk. 9: 149. 1899. TYPE: Paraguay, near Estancia Tagatiya, 25 January 1898, Anisits 17. LECTOTYPE: B, designed by Leuenberger (2002: 432). Fig. 8 H-K

Opuntia assumptionis K. Schum.,Monatsschr. Kakteenk. 9: 153. 1899. TYPE: Paraguay, bei Asunción, 3 March 1898, Anisits 63.HOLOTYPE: B. Syn. nov.

Opuntia subsphaerocarpa Speg., Anales Soc. Ci. Argent. 99: 104. 1925. TYPE: photograph published by Spegazzini (1925: 105). LECTOTYPE: designated here. Syn. nov.

Opuntia cognata F. Ritter ex P.J. Braun \& Esteves, Succulenta (Netherlands) 74: 132. 1995. Platyopuntia cognata F. Ritter, Kakteen Südamerica 1: 246. 1979. nom. illeg. TYPE: 
Paraguay, Alto Paraguay, Puerto Casado, 1963, Ritter 1202. HOLOTYPE: U. ISOTYPE: SGO. Syn. nov.

DESCRIPTION: Erect shrubs or subshrubs, sometimes prostrate, 1.5 (2) m tall, branched; branches rarely with adventitious roots when contacting the soil. Stem segments green to dark green, shiny, with variable shapes: oblong, elliptical, lanceolate to obovate, (8) 10-30 (37) cm long, (3) 4-8 (9) cm wide and (1) $1.5 \mathrm{~cm}$ thick. Areoles (10) 15-20 (30) on each side, ovate or elliptic, 3-5 $\mathrm{mm}$ diam., sometimes protuberant, with white tomentum and reddish-brown glochids. Stem segment epidermis sometimes with purple stripes below the areoles. Spines 02 (3) in each areole, (1) 4-5 (6) cm long, subulate to acicular, whitish to greyish, straight to twisted. Flower buds with acute apex. Flowers with yellow or yellow-orange (rarely orange), tepals ca. $6 \mathrm{~cm}$ diam. when open. Pericarpel (2) 3-4 $\mathrm{cm}$ in length, with areoles sometimes having conspicuous reddish-brown groups of glochids. Style obclaviform, creamy, stigma with 6-8 creamy lobes. Fruit purple-violet with greenish inner pulp, obovate, pyriform to globose, with umbilicate apex, (2.5) 4-5 (5.5) cm long x 1.5-3 (3.5) cm diam. Seeds lenticular, (2.5) 3.5-4 (4.5) mm diam. x 1-1.5 mm thick, with conspicuous pubescent arils.

DISTRIBUTION AND HABITAT: Central Paraguay (Alto Paraguay, Central, Concepción, Cordillera, Ñeembucú, Presidente Hayes and San Pedro) and NE Argentina (Chaco, Corrientes, Entre Ríos, Formosa and Santa Fe). It grows on the edge and within dry forests, mainly on alkaline clay soils.

\section{Infraspecific variation of Opuntia megapotamica}

For this polymorphic species, two varieties are proposed (one new combination and one new to science), based on phenotypic differences easily observed in the field (see identification key). 
Opuntia megapotamica Arechav.var. megapotamica,Anales Mus. Nac. Montevideo ser. 2, 1: 42. 1905. TYPE: tab. 32 in Arechavaleta (1902: 275) sub nomen Opuntia monacantha. LECTOTYPE: designated by Leuenberger (2002)

Opuntia atrovirens Speg., Anales Soc. Ci. Argent.99: 91. 1925.TYPE: Argentina, Entre Ríos, Dpt. Feliciano, Arroyo Feliciano, ruta 12 cerca de San José de Feliciano, 11 March 1962, Burkart et al. 23414 (SI). NEOTYPE: here designated.

Opuntia prasinaSpeg., Anales Soc. Ci. Argent.99: 103. 1925. TYPE: Argentina, Buenos Aires, Pdo. Moreno, ruta 25 y Arroyo Arias, December 1986, Font 417 (BAF). NEOTYPE: designated by Font (2014: 75)

Opuntia brunneogemmia F. Ritter ex C. Schlindwein, Bradleya 13: 29. 1995. Platyopuntia brunneogemmia F. Ritter, Kakteen Südam. 1: 34-35, 1979. nom. illeg. TYPE: Brasil, Rio Grande do Sul, Quarita, 1965, Ritter 1408.HOLOTYPE: U

DESCRIPTION: Erect shrubs up to 1.5 (2) m tall, branched, sometimes with a well-defined trunk. Stem segments orbicular to suborbicular, sometimes subspatulate,25-30 (40) cm long, (15) $20 \mathrm{~cm}$ wide, and 2-2.5 cm thick, green or grayish-green, 15-30 elliptic areoles on each side, with conspicuous groups of reddish-brown- glochids $6 \mathrm{~m}$ min length and with 0-2 (3) subulate whitish rigid spines $2.5-10 \mathrm{~cm}$ in length. Flower buds with acute apex. Flowers with orange to yellow-orange tepals, 6-7.5 (9) $\mathrm{cm}$ diam. when open, arranged on the upper edge of the stem segments. Pericarpel $6(7.5) \mathrm{cm}$ long. Style obclaviform, white to pink, stigma with 10 greenish lobes. Fruits obconic or obpyriform, 5-7 cm long x 3-5 cm diam., purplish red without, with wine red inner pulp. Seeds with glabrescent arils, lenticular, 4-5 mm diam. and $2 \mathrm{~mm}$ thick. 
DISTRIBUTION AND HABITAT: E Argentina (Buenos Aires, Corrientes, Entre Ríos and Santa Fe) and SW Brazil and Uruguay. It grows in well drained soils and anthropogenicareas (railroads, fences edges).

Opuntia megapotamica Arechav. var. salagria (A. Cast.) Oakley comb. et stat. nov. Fig. $8 \mathrm{~N}$

BASIONYM: Opuntia salagria A. Cast., Lilloa 27: 85. 1955. TYPE: Argentina, Buenos Aires, Campana, 20 November 1951, Castellanos s. n. (BA 54768).LECTOTYPE: designated by Leuenberger (2002: 431)

It differs from the typical variety by its more glaucous slender stem segments of $1-1.5 \mathrm{~cm}$ thick and by having more areoles (35-40) on each side. Areoles have 2 (3) thin, slightly subulate spines, up to $4 \mathrm{~cm}$ long. The pericarpel has small spines on the upper margin up to 8 mm long.

DISTRIBUTION AND HABITAT: Endemic to Central Argentina (Buenos Aires, Catamarca, Córdoba, Entre Ríos, La Pampa, Santa Fe, Santiago del Estero and San Luis). It grows on well drained soils or rocky areas.

Opuntia megapotamica Arechav. var. chadihuensis Oakley \& Villamil var. nov. Fig. 8 L-N A varietate typica articulis elliptico-obovatis vel subspatulate, crassius, minus areolis parvis, submersis, aculeis 0 vel brevispinus et gracilibus, differt.

TYPE: Argentina, Buenos Aires, Part. Coronel Rosales, Villa Arias, 15 May 1999, Villamil 9009. HOLOTYPE: BBB. 
ETYMOLOGY: from the Mapuche language: "chadi" = salt and "hue"= place, as it grows in salty environments.

It is distinguished by its thicker elliptical-obovate or subspatulate stem segments, from 2.5 to $3 \mathrm{~cm}$ thick, either intense grayish-green or glaucous. It has 15-20 areoles on each side with sunken borders, mostly with no spines or rarely with a single slender spine up to $3.5 \mathrm{~cm}$ long. The mesocarp is intensely wine-colored, probably due to a higher concentration of betacyanine, as reported for varieties of other Opuntia species (Aquino Bolaños et al. 2012).

DISTRIBUTION AND HABITAT: This variety is so far restricted to SW Buenos Aires province in Argentina, where it thrives in soils that are not well-drained and that accumulate salt on the surface.

\section{Acknowledgements}

Funding was provided by CONICET, FONCyT and SECyT-UNC from Argentina.The authors are grateful to the curators and directors of the herbaria $\mathrm{BA}, \mathrm{BAB}, \mathrm{BACP}, \mathrm{BBB}$, CORD, CTES, FCQ, LIL, LP, PY, SF, SI, and UNR, to D. Uñates for helping with the illustrations, to R. Kiesling for providing samples of $O$. monacantha, to A. Long for providing samples of O. penicilligera, to D. Chamorro, P. Demaio, L. Galetti, H. Maturo, D. Palou, S. Torrella, J. Adámoli, D. Prado, and C. Villamil for helping with the field work, and to G. González and G. Kenicer for helping with the pictures.Anonymous reviewers provided valuable comments and suggestions that improved the manuscript.

\section{References}


Adams, S.P., Leitch, I.J., Bennett, M.D., and Leitch, A.R. 2000. Aloe L.-a second plant family without (TTTAGGG) n telomeres. Chromosoma,109(3): 201-205. doi:10.1007/s004120050429.

Anderson, E.F. 2001. The cactus family. Timber Press, Portland.

Aquino Bolaños, E.N., Moctezuma, Y.C., Servia, J.L.C., Guzmán, R.I.G., Hernández, E.R.S., and Verdalet Guzmán, I. 2012. Caracterización fisicoquímica de siete variedades de tuna (Opuntia spp.) color rojo-violeta y estabilidad del pigmento de las dos variedades con mayor concentración1. Invest. Ci. Univ. Auton. Aguascalientes,3:1821-1910.

Arechavaleta, J. 1902. Cactáceas. Anal. Mus. Hist. Nat. Montevideo,5(2): 161-291.

Bandyopadhyay, B., and Sharma, A. 2000. The use of multivariate analysis of karyotypes to determine relationships between species of Opuntia (Cactaceae). Caryologia,53(2): 121126. doi:10.1080/00087114.2000.10589186.

Bárcenas, R.T. 2015.A molecular phylogenetic approach to the systematics of Cylindropuntieae (Opuntioideae, Cactaceae) [on line]. Cladistics, doi:10.1111/cla.12135.

Barthlott, W., and Hunt, D.R. 1993. Cactaceae. In The families and genera of vascular plants 2. Edited by K.Kubitzki. Springer-Verlag, Berlin. pp. 161-197.

Benko-Iseppon, A.M., and Morawetz, W. 2000. Cytological comparison ofCalyceraceae and Dipsacaceae with special reference to theirtaxonomic relationships. Cytologia,65(2):123128.

Buxbaum, F. 1953. Morphology of cacti. Section II: Flower. Abbey Garden Press, Pasadena.

Castro, J.P., Medeiros-Neto, E., Souza, G., Alves, L.I., Batista, F.R., and Felix, L.P. 2016. CMA band variability and physical mapping of 5S and 45S rDNA sites in Brazilian Cactaceae: Pereskioideae and Opuntioideae [on line]. Brazil. J. Bot. doi:10.1007/s40415015-0248-5. 
Cota, J.H., and Philbrick, C.T. 1994. Chromosome number variation and polyploidy in the genus Echinocereus. Am. J. Bot.81(8): 1054-1062.

Cota, J.H., and Wallace, R.S. 1995. Karyotypic studies in the genus Echinocereus and its taxonomic implications. $\quad$ Caryologia,48(2): 105-122. doi:10.1080/00087114.1995.10797321

Corner, E.J.H. 1976. The seeds of dicotyledons (Vol. 1). Cambridge University Press, Cambridge.

Chiarini, F., Santiñaque, F., Urdampilleta, J. D., and Las Peñas, M. L. 2014. Genomic diversity in Solanum sect. Acanthophora (Solanaceae). Pl. Syst. Evol. 300(1):113125.doi:10.1007/s00606-013-0864-0.

Crook, R., and Mottram, R. 1996. Opuntia Index: part 2: nomenclatural note and C-E. Bradleya, 14: 99-144.

Das, A.B., and Mohanty, S. 2006. Karyotype analysis and in situ nuclear DNA content in seven species of Echinopsis Zucc. of the family Cactaceae. Cytologia,71(1): 75-79.

Crook, R., and Mottram, R. 2000. Opuntia Index: part 6: M-O. Bradleya,18: 113-140.

Di Rienzo, J.A., Casanoves, F., Balzarini, M.G., Gonzalez, L., Tablada, M., and Robledo, C.W. 2012. InfoStat versión 2012. Grupo InfoStat, FCA, Universidad Nacional de Córdoba, Argentina. URL http://www.infostat.com.ar.

Eggli, U. 2002. Synopsis of the Cactaceae of Mato Grosso, Brazil. Haseltonia,9(1):146-166.

Engleman, E.M. 1960. Ovule and seed development in certain cacti. Am. J. Bot. 47(6):460467.

Font, F. 2014. A revision of Opuntia serie Armatae K. Schum. (Opuntia ser. Elatae Briton \& Rose (Cactaceae-Opuntioideae). In Further studies in the Opuntioideae (Cactaceae). Succulent Plant Research 8. Edited byD. Hunt. David Hunt Books, Milborne Port. pp.5194. 
García, S., Gálvez, F., Gras, A., Garnatje, T., and Kovarik, A. 2013. Plant rDNA database release 2.0, including new features. Avaliable from: http://www.plantrdnadatabase.com. [accessed 5 February 2016].

Gerlach, W.L., and Bedbrook, J.R. 1979. Cloning and characterization of ribosomal RNA genes from wheat and barley. Nucl. Acids Res. 7(7):1869-1885. doi:10.1093/nar/7.7.1869.

Goldblatt, P., and Johnson, D.E. 2013. Index to plant chromosome numbers Missouri Botanical Garden. Avaliable from: http://www.tropicos.org/Project/IPCN [accessed 5 February 2016].

Griffith, M.P., and Porter, J.M. 2009. Phylogeny of Opuntioideae (Cactaceae). Int. J. P1. Sci. 170(1): 107-116. doi:10.1086/593048.

Guerra, M. 2000. Patterns of heterochromatin distribution in plant chromosomes. Genet. Mol. Biol. 23(4): 1029-1041. doi:10.1590/S1415-47572000000400049.

Hernández, H.M., Goméz-Hinostrosa, C., Bárcena, R., Puente, R., and Reyes-Agüero, O. 2014. A checklist of the subfamilia Opuntioideae (Cactaceae) from North and Central America. In Further studies in the Opuntioideae (Cactaceae). Succulent Plant Research 8. Edited by D. Hunt. David Hunt Books, Milborne Port. pp.185-200.

Hijmans, R.J., Guarino, L., and Rojas, E. 2002. DIVA-GIS, version 2. A geographic information system for the analysis of biodiversity data. Manual. International Potato Center, Lima.

Hunt, D., Taylor, N., and Graham, C. 2006. The new cactus lexicon: descriptions and illustrations of the cactus family. David Hunt Books, Milborne Port.

Jiang, J., and Gill, B.S. 2006. Current status and the future of fluorescence in situ hybridization (FISH) in plant genome research. Genome, 49(9): 1057-1068. doi:10.1139/g06-076. 
Kiesling, R. 1975. Los géneros de Cactaceae de Argentina. Bol. Soc. Argent. Bot. 45(3): 183227.

Kiesling, R. 1984a. Estudios en Cactaceae de Argentina: Maihueniopsis, Tephrocactus y géneros afines (Opuntioideae). Darwiniana,25(1-4): 171-215.

Kiesling, R. 1984b. Recopilación en edición fascimilar, de todos los trabajos o referencias sobre Cactaceae publicadas por el Dr. Carlos Spegazzini. Libro Sur Ediciones, Quilmes.

Kiesling, R. 1999. New synonyms of Opuntia ficus-indica (Cactaceae). Hickenia, 2(66): 309314.

Kiesling, R., Saravia, M., Oackley, L., Muruaga, N., Metzing, D., and Novara, L. 2011. Flora del Valle de Lerma. Cactaceae Juss. Aportes Bot. Salta-Ser. Flora,10(7): 1-142.

Las Peñas, M.L., Bernardello, G., and Kiesling, R. 2008. Karyotypes and fluorescent chromosome banding in Pyrrhocactus (Cactaceae). Pl. Syst. Evol. 272(4): 211-222. doi:10.1007/s00606-007-0611-5.

Las Peñas, M.L., Kiesling, R., and Bernardello, G. 2011. Karyotype, heterochromatin, and physical mapping of 5S and 18-5.8-26S rDNA genes in Setiechinopsis (Cactaceae), an Argentine endemic genus. Haseltonia,16(1): 83-90. doi:10.2985/1070-0048-16.1.83

Las Peñas, M.L., Urdampilleta, J.D., Bernardello, G., and Forni-Martins, E.R. 2009. Karyotypes, heterochromatin, and physical mapping of 18S-26S rDNA in Cactaceae. Cytogen. Genome Res. 124(1): 72-80. doi:10.1159/000200090.

Las Peñas, M.L., Urdampilleta, J.D., López-Carro, B., Santiñaque, F., Kiesling, R., and Bernardello, G. 2014. Classical and molecular cytogenetics and DNA content in Maihuenia and Pereskia (Cactaceae). Pl. Syst. Evol. 300(3): 549-558. doi:10.1007/s00606-013-0903$\mathrm{x}$.

Leitch, A.R., and Leitch, I.J. (2008) Genomic plasticity and the diversity of polyploid plants. Science,320:481-483. DOI: 10.1126/science.1153585. 
Leuenberger, B.E. 2001. The type specimen of Opuntia cardiosperma (Cactaceae), new synonyms and new records for Argentina and Paraguay. Willdenowia,31(1): 171179.doi:10.3372/wi.31.31115.

Leuenberger, B.E. 2002. The South American Opuntia ser. Armatae (= O. ser. Elatae)(Cactaceae). Bot. Jahrb. Syst.123(4): 413-439.

Leuenberger, B.E., and Arroyo-Leuenberger, S. 2014. Northern hemisphere Opuntia and Cylindropuntia species (Cactaceae) naturalized in Argentina -and the riddle of Opuntiapenicilligera. Succ. P1. Res. 8: 95-118.

Lichtenzveig, J., Abbo, S., Nerd, A., Tel-Zur, N., and Mizrahi, Y. 2000. Cytology and mating systems in the climbing cacti Hylocereus and Selenicereus. Am. J. Bot. 87(7): 1058-1065.

Machado, M.C. 2008. Notes on Brazilian taxa of series Armatae(Elatae). Cact. Syst. Init. 24: $33-35$.

Majure, L.C., Judd, W.S., Soltis, P.S., and Soltis, D.E. 2012a. Cytogeography of the Humifusa clade of Opuntia ss Mill. 1754 (Cactaceae, Opuntioideae, Opuntieae): correlations with pleistocene refugia and morphological traits in a polyploid complex. Comp. Cytogen. 6(1): 53-77. doi:10.3897/CompCytogen.v6i1.2523.

Majure, L.C., Puente, R., Griffith, M.P., Judd, W.S., Soltis, P.S., and Soltis, D.E. $2012 b$. Phylogeny of Opuntia ss (Cactaceae): clade delineation, geographic origins, and reticulate evolution. Am. J. Bot. 99(5): 847-864. doi:10.3732/ajb.1100375.

Majure, L.C., Puente, R., and Pinkava, D.J. 2012c. Miscellaneous chromosome numbers in Opuntieae DC.(Cactaceae) with a compilation of counts for the group. Haseltonia,18(1): 67-78. doi:10.2985/026.018.0109.

Moreno, N.C., Amarilla, L.D., Las Peñas, M.L., and Bernardello, G. 2015a. Molecular cytogenetic insights into the evolution of the epiphytic genus Lepismium (Cactaceae) and related genera. Bot. J. Linn. Soc. 177(2): 263-277. doi:10.1111/boj.12242. 
Moreno, N.C., Las Peñas, M.L., and Bernardello, G. 2015b. Karyotypes, Heterochromatin and Physical Mapping of rDNA in Vine Cactaceae (Hylocereineae). Haseltonia,20(1): 2633. doi:10.2985/026.020.0106.

Moscone, E.A., Klein, F., Lambrou, M., Fuchs, J., and Schweizer, D. 1999. Quantitative karyotyping and dual-color FISH mapping of $5 \mathrm{~S}$ and $18 \mathrm{~S}-25 \mathrm{~S}$ rDNA probes in the cultivated Phaseolus species (Leguminosae). Genome,42(6): 1224-1233. doi:10.1139/g99070.

Negrón-Ortiz, V. 2007. Chromosome numbers, nuclear DNA content, and polyploidy in Consolea (Cactaceae), an endemic cactus of the Caribbean Islands. Am. J. Bot. 94(8): 1360-1370. doi:10.3732/ajb.94.8.1360.

Osten, C. 1941. Notas sobre Cactáceas. Anal. Mus. Hist. Nat. Montevideo 2a Ser. 5(1): 1-83. Palomino, G., and Heras, H.M. 2001. Karyotypic studies in Opuntia cochinera, O. hyptiacantha, and O. strepthacantha (Cactaceae). Caryologia,54(2): 147-154. doi:10.1080/00087114.2001.10589221.

Palomino, H.G., Zuleta, S., and Scheinvar, L. 1988. Estudios citogenéticos de dos especies y una variedad del género Nyctocereus (Cactaceae). Bol. Soc. Bot. México 40: 75-80.

Pinkava, D.J. 2002. On the evolution of the continental North American Opuntioideae. In Studies in the Opuntioideae (Cactaceae). Succulent plant research 6. Edited byD.Hunt, and N. Taylor.David Hunt Books, Milborne Port. pp.59-98.

Powell, A.M., and Weedin, J.F. 2001. Chromosome numbers in Chihuahuan Desert Cactaceae. III. Trans-Pecos Texas. Am. J. Bot. 88(3): 481-485.

Pringle, G.J., and Murray, B.G. 1993. Karyotypes and C banding patterns inspecies of Cyphomandra Mart. ex Sendtn. (Solanaceae). Bot. J. Linn. Soc. 111(3): 331-342.doi: 10.1111/j.1095-8339.1993.tb01907.x. 
Raskina, O., Barber, J.C., Nevo, E., and Belyayev, A. 2008. Repetitive DNA and chromosomal rearrangements: speciation-related events in plant genomes. Cytogen. Genome Res. 120(3-4): 351-357. doi:10.1159/000121084.

Realini, M.F., González, G.E., Font, F., Picca, P.I., Poggio, L., and Gottlieb, A.M. 2015. Phylogenetic relationships in Opuntia (Cactaceae, Opuntioideae) from southern South America. P1. Syst. Evol. 301(4): 1123-1134. doi:10.1007/s00606-014-1154-1.

Realini, M.F., Gottlieb, A.M, Font, F., Picca, P., Poggio, L., and González G.E. 2014. Cytogenetic characterization of southern South American species of Opuntia (CactaceaeOpuntioideae). In Further studies in the Opuntioideae (Cactaceae). Succulent Plant Research 8. Edited byD. Hunt. David Hunt Books, Milborne Port. pp.31-50.

Remski, M.F. 1954. Cytological investigations in Mammillaria and some associated genera. Bot. Gaz.116(2): 163-171.

Reyes-Agüero, J.A., Aguirre, J.R., and Valiente-Banuet, A. 2006. Reproductive biology of Opuntia: a review. J. Arid Envir. 64(4): 549-585. doi:10.1016/j.jaridenv.2005.06.018.

Ritz, C.M., Reiker, J., Charles, G., Hoxey, P., Hunt, D., Lowry, M., Stuppy, W., and Taylor, N. 2012. Molecular phylogeny and character evolution in terete-stemmed Andean opuntias (Cactaceae-Opuntioideae). Mol. Phylog. Evol. 65(2): $\quad$ 668681.doi:10.1016/j.ympev.2012.07.027

Roa, F., and Guerra, M. 2012. Distribution of 45S rDNA sites in chromosomes of plants: Structural and evolutionary implications. BMC Evol. Biol. 12(1): 225. doi:10.1186/14712148-12-225.

Schumann, K. 1899. Die Cactaceae der Republik Paraguay III. Gattung Cereus. Monatsschr. Kakteenk. 9: 185-188.

Schwarzacher, T., Ambros, P., and Schweizer, D. 1980. Application of Giemsa banding to orchid karyotype analysis. Pl. Syst. Evol.134(3-4): 293-297. doi:10.1007/BF00986805. 
Schwarzacher, T., and Heslop-Harrison, P. 2000. Practical in situ Hybridization. BIOS Scientific Publ., Oxford.

Schweizer, D. 1976. Reverse fluorescent chromosome banding with chromomycin and DAPI. Chromosoma,58(4): 307-324. doi:10.1007/BF00292840.

Schweizer, D., and Ambros, P.F. 1994. Chromosome banding. In Chromosome Analysis Protocols Vol. 29 Methods in Molecular Biology. Edited by Gosden, J. Humana Press, Totowa. pp. 97-112. doi:10.1385/0-89603-289-2:97.

Spegazzini, C. 1925. Nuevas Notas Cactológicas. Anal. Soc. Ci. Argent. 99: 85-146.

Stiefkens, L., Las Peñas, M.L., Bernardello, G., Levin, R.A., and Miller, J.S. 2010. Karyotypes and fluorescent chromosome banding patterns in southern African Lycium (Solanaceae). Caryologia,63(1): 50-61. doi:10.1080/00087114.2010.10589708.

Stuppy, W. 2002. Seed characters and the classification of the Opuntioideae. In Studies in the Opuntioideae (Cactaceae). Succulent plant research 6. Edited byD. Hunt, and N. Taylor. David Hunt Books, Milborne Port. pp. 25-58.

Sumner, A.T. 1990. Chromosome banding. Unwin Hyman, London.

Taketa, S., Ando, H., Takeda, K., Ichii, M., and von Bothmer, R. 2005. Ancestry of American polyploid Hordeum species with the Igenome inferred from $5 \mathrm{~S}$ and $18 \mathrm{~S}-25 \mathrm{~S}$ rDNA. Ann. Bot. 96(1): 23-33. doi:10.1093/aob/mci147.

Taylor, N., and Zappi, D. 2004. Cacti of Eastern Brazil. The Royal Botanic Gardens, Kew.

Thiers, B. [continuously updated]. Index Herbariorum: A global directory of public herbaria and associated staff. New York Botanical Garden's Virtual Herbarium. http://sweetgum.nybg.org/ih/ [accessed 14 February 2016].

Vaupel, F. 1913. Opuntia DeLaetiana Weber n. spec. In Blühende Kakteen (Iconographia Cactacearum) 3: t. 148.Edited byK. Schumann. J. Neumann, Neudamm.

Walther, E. 1930. Species. Cact. Succ. J. (Los Angeles) 1(11): 203-205. 
Table 1. Collection data of populations studied of Opuntia ser. Armatae, indicating the herbarium where vouchers are deposited. Compare with Fig. 1.

\begin{tabular}{|c|c|c|c|}
\hline & Taxa & Collection data & Code \\
\hline \multirow{9}{*}{ 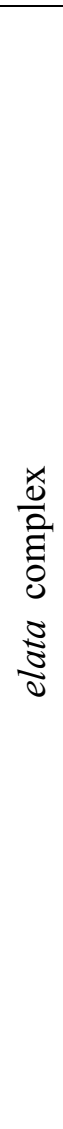 } & \multirow{2}{*}{$\begin{array}{l}\text { O. elata var. } \\
\text { cardiosperma(K. Schum.) } \\
\text { R. Kiesling }\end{array}$} & $\begin{array}{l}\text { Santa Fe, Dpt.Vera, } 29^{\circ} 25^{\prime} 31.5^{\prime \prime} \mathrm{S} / 60^{\circ} 23^{\prime} 25^{\prime \prime} \mathrm{W} \text {, } \\
\text { Chamorro s.n. (UNR). }\end{array}$ & E1 \\
\hline & & $\begin{array}{l}\text { Formosa, Dpt. Patiño, } 25^{\circ} 00^{\prime} 55.8^{\prime \prime} \mathrm{S} / 60^{\circ} 41^{\prime} 55.3^{\prime \prime} \\
\text { W, Oakley } 149 \text { (UNR). }\end{array}$ & E2 \\
\hline & \multirow{3}{*}{$\begin{array}{l}\text { O. elataSalm-Dyck var. } \\
\text { elata }\end{array}$} & $\begin{array}{l}\text { Corrientes, Dpt. Esquina, } 30^{\circ} 13^{\prime} 9^{\prime \prime} \mathrm{S} / 59^{\circ} 13^{\prime} 32^{\prime \prime} \\
\text { W,Galetti s.n. (UNR). }\end{array}$ & E3 \\
\hline & & $\begin{array}{l}\text { Entre Ríos,Dpt.Diamante,32 } 32^{\circ} 09^{\prime} 28.01^{\prime \prime} \mathrm{S} / 60^{\circ} 31^{\prime} \\
50.87^{\prime} \text { W, Oakley and Palou } 075 \text { (UNR). }\end{array}$ & E4 \\
\hline & & $\begin{array}{l}\text { Formosa, Dpt. Patiño, } 24^{\circ} 25^{\prime} 01.8^{\prime} \text { ' S / } 61^{\circ} 00^{\prime} \\
23.9^{\prime \prime} \text { W, Oakleyet al. } 102 \text { (UNR). }\end{array}$ & E5 \\
\hline & $\begin{array}{l}\text { O. elata var. obovata } \mathrm{E} \text {. } \\
\text { Whalter }\end{array}$ & $\begin{array}{l}\text { Santa Fe, Dpt. Rosario, } 33^{\circ} 01^{\prime} 27.89^{\prime} \text { S / } 60^{\circ} 54^{\prime} \\
\text { 07.69'” W, Galetti s.n. (UNR). }\end{array}$ & E6 \\
\hline & \multirow{3}{*}{ O. sternarthra K. Schum. } & $\begin{array}{l}\text { Formosa, Dpt. Patiño,24 } 26^{\prime} 31.7^{\prime \prime} \mathrm{S} / 60^{\circ} 40^{\prime} 51.5^{\prime \prime} \\
\text { W, Oakley et al. } 106 \text { (UNR). }\end{array}$ & S1 \\
\hline & & $\begin{array}{l}\text { Santa Fe, Dpt. Vera,29 } 23^{\circ} 12.3^{\prime \prime} \mathrm{S} / 60^{\circ} 33^{\prime} 08.1^{\prime \prime} \\
\text { W,Oakley et al.95 (UNR). }\end{array}$ & S2 \\
\hline & & $\begin{array}{l}\text { Corrientes, Dpt. Esquina, } 30^{\circ} 13^{\prime} 10.04^{\prime \prime} \mathrm{S} / 59^{\circ} 13^{\prime} \\
38.80^{\prime}{ }^{\prime} \mathrm{W} \text {, Galetti s.n. (UNR). }\end{array}$ & S3 \\
\hline
\end{tabular}




\begin{tabular}{|c|c|c|c|}
\hline & & $\begin{array}{l}\text { Formosa,Dpt. Patiño,25'01' } 57^{\circ} \text { ' S / } 60^{\circ} 42^{\prime} 39.2^{\prime \prime} \\
\text { W,Oakley } 150 \text { (UNR). }\end{array}$ & S4 \\
\hline \multirow{9}{*}{ 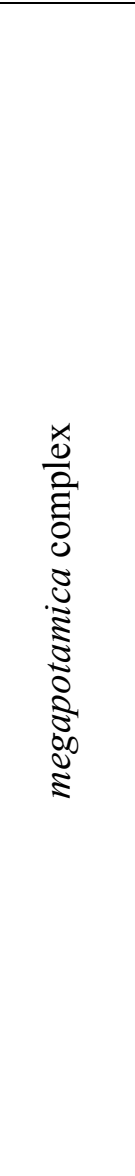 } & O. bonaerensis Speg. & $\begin{array}{l}\text { Entre Ríos, Dpt. Victoria, } 32^{\circ} 34^{\prime} 56.35^{\prime \prime} \mathrm{S} / 60^{\circ} 10^{\prime} \\
43.82^{\prime} \text { W, Oakley and Palou } 77 \text { (UNR). }\end{array}$ & B1 \\
\hline & $\begin{array}{l}\text { O. megapotamica var. } \\
\text { chadihuensis Oakley \& } \\
\text { Villamil }\end{array}$ & $\begin{array}{l}\text { Buenos Aires, Part. Coronel Rosales, } 38^{\circ} 48^{\prime} 12.01^{\prime \prime} \\
\text { S / } 62^{\circ} 06^{\prime} 32.33^{\prime \prime} \mathrm{W} \text {, Oakley and Villamil } 49 \\
\text { (UNR). }\end{array}$ & M6 \\
\hline & \multirow{5}{*}{$\begin{array}{l}\text { O. megapotamica } \\
\text { Arechav. var. } \\
\text { megapotamica }\end{array}$} & $\begin{array}{l}\text { Entre Ríos, Dpt. Paraná, } 31^{\circ} 53^{\prime} 15^{\prime \prime} \mathrm{S} / 60^{\circ} 24^{\prime} \\
8.55^{\prime \prime} \mathrm{W} \text {, Oakley and Palou } 74 \text { (UNR). }\end{array}$ & M1 \\
\hline & & $\begin{array}{l}\text { Entre Ríos, Dpt. Victoria, } 32^{\circ} 33^{\prime} 12.04^{\prime \prime} \mathrm{S} / 60^{\circ} 01^{\prime} \\
\text { 49.16” W, Oakley and Palou } 76 \text { (UNR). }\end{array}$ & M2 \\
\hline & & $\begin{array}{l}\text { Entre Ríos, Dpt. Paraná, } 31^{\circ} 28^{\prime} 44.7^{\prime \prime} \mathrm{S} / 59^{\circ} 54^{\prime} \\
16.7^{\prime} \text { W, Oakley et al. } 78 \text { (UNR). }\end{array}$ & M3 \\
\hline & & $\begin{array}{l}\text { Santa Fe, Dpt. Constitución, } 33^{\circ} 16^{\prime} 21.83^{\prime \prime} \mathrm{S} / 60^{\circ} \\
50^{\prime} 06.87^{\prime} \text { 'W, Oakley } 48 \text { (UNR). }\end{array}$ & M4 \\
\hline & & $\begin{array}{l}\text { Entre Ríos, Dpt. La Paz, } 31^{\circ} 17^{\prime} 33.1^{\prime \prime} \mathrm{S} / 59^{\circ} 47^{\prime} \\
\text { 30.2” W, Oakley et al. } 79 \text { (UNR). }\end{array}$ & M5 \\
\hline & $\begin{array}{l}\text { O. megapotamica var. } \\
\text { salagria (A. Cast.) } \\
\text { Oakley }\end{array}$ & Córdoba, Dpt. Colón, Oakley s.n. (UNR). & M7 \\
\hline & O. penicilligera Speg. & Buenos Aires, Part. Bahía Blanca, Long s.n. (UNR). & P1 \\
\hline 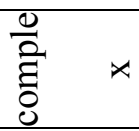 & O. arechavaletae & Santa Fe, Dpt. San Jerónimo, $32^{\circ} 13^{\prime} 57^{\prime \prime} \mathrm{S} / 60^{\circ}$ & A1 \\
\hline
\end{tabular}




\begin{tabular}{|c|c|c|}
\hline \multirow[t]{2}{*}{ Arechav. } & 57’22’' W, Palou s.n. (UNR). & \\
\hline & Entre Ríos, Dpt.Victoria, Palou s.n. (UNR). & A2 \\
\hline \multirow{2}{*}{ O. monacantha Haw. } & $\begin{array}{l}\text { Córdoba, Dpt. Capital, cultivated in Jardín Zoológico, } \\
\text { Las Peñas and Moreno } 640 \text { (CORD). Origin Brazil. }\end{array}$ & $\mathrm{O} 1$ \\
\hline & $\begin{array}{l}\text { Córdoba, Dpt. Capital, cultivated, Las Peñas } 641 \\
\text { (CORD). Origin Brazil. }\end{array}$ & $\mathrm{O} 2$ \\
\hline
\end{tabular}


Table 2. Comparison of the species' circumscriptions of Opuntia ser. Armataerevisions.

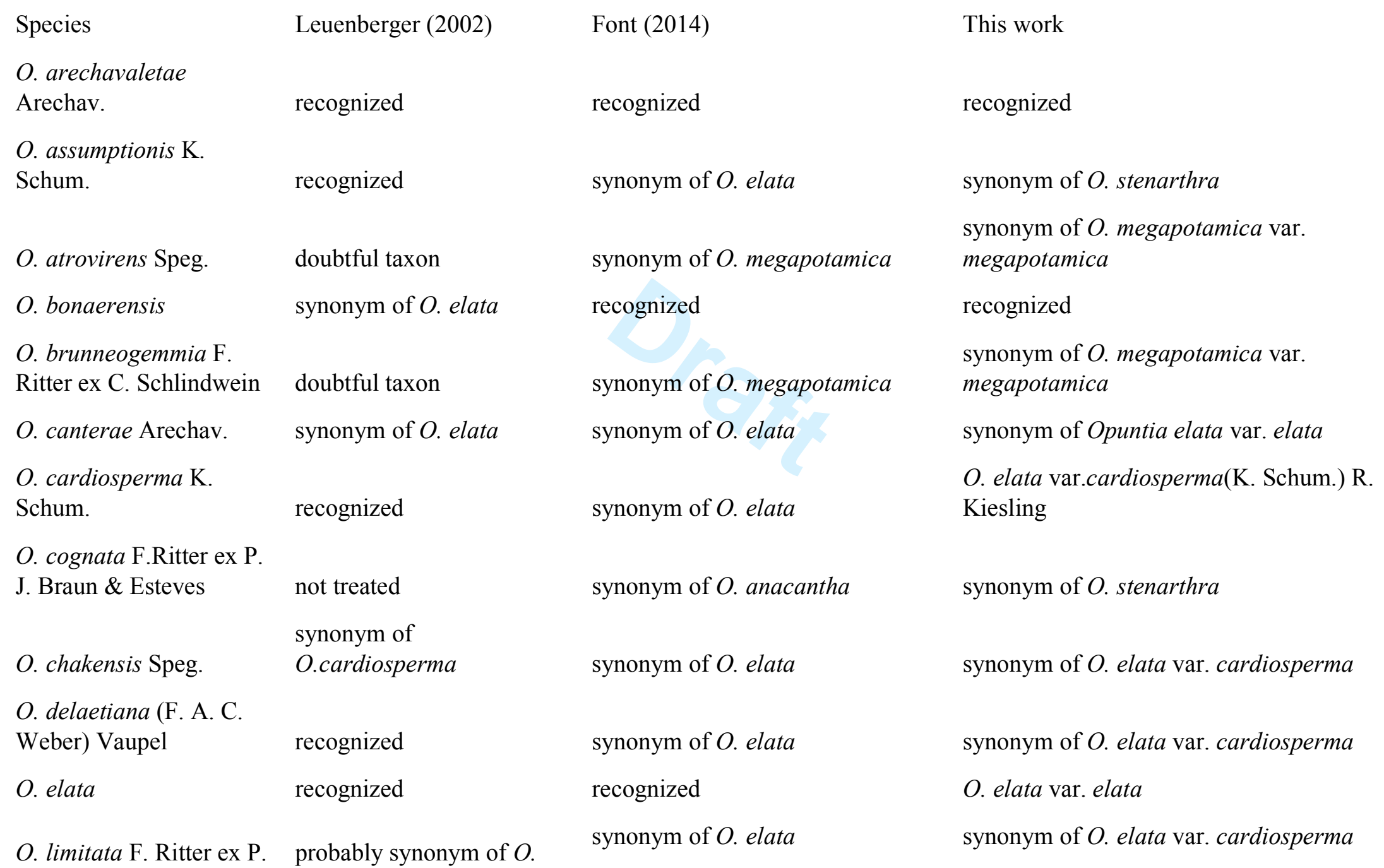




\begin{tabular}{|c|c|c|c|}
\hline J. Braun \& Esteves & elata & & \\
\hline O. megapotamica & recognized & recognized & O. megapotamica var. megapotamica \\
\hline O. mieckleyi K. Schum. & $\begin{array}{l}\text { synonym of } O . \\
\text { cardiosperma }\end{array}$ & synonym of $O$. elata & synonym of $O$. elata var. cardiosperma \\
\hline O. monacantha & recognized & recognized & recognized \\
\hline O. penicilligera & not treated & recognized & recognized \\
\hline O. prasina Speg. & synonym of $O$. elata & synonym of $O$. megapotamica & $\begin{array}{l}\text { synonym of } O . \text { megapotamica var. } \\
\text { megapotamica }\end{array}$ \\
\hline $\begin{array}{l}\text { O. pyrrhantha F. Ritter ex } \\
\text { P. J. Braun \& Esteves }\end{array}$ & $\begin{array}{l}\text { probably synonym of } O \text {. } \\
\text { elata }\end{array}$ & synonym of $O$. elata & synonym of $O$. elata var. elata \\
\hline O. rioplatense Font & O. elata pro parte & recognized & O. elata var. obovata E. Whalter \\
\hline O. salagria A. Cast. & $\begin{array}{l}\text { synonym of } O . \\
\text { megapotamica }\end{array}$ & synonym of $O$. megapotamica & $\begin{array}{l}\text { O. megapotamica var. salagria(A. Cast.) } \\
\text { Oakley }\end{array}$ \\
\hline O. stenarthra & recognized & synonym of $O$. anacantha & recognized \\
\hline O. subsphaerocarpa Speg. & doubtful taxon & synonym of $O$. anacantha & synonym of $O$. stenarthra \\
\hline $\begin{array}{l}\text { O. viridirubra F. Ritter ex } \\
\text { P. J. Braun \& Esteves }\end{array}$ & doubtful taxon & synonym of $O$. arechavaletae & doubtful taxon \\
\hline
\end{tabular}


Table 3.Cytogenetical features of Opuntia ser. Armatae.2n, somatic chromosome number;TL,mean total chromosome length;TLH, mean total haploid chromosome length; \%Ht, heterochromatin amount expressed as percentage of the karyotype length;C, mean chromosome length; $\mathbf{C M A}^{+} / \mathbf{N O R}$, number ofchromosome pairs with $\mathrm{CMA}^{+} / \mathrm{DAPI}^{-} \mathrm{NOR}$ associated bands;CMA, position ofCMA ${ }^{+} / \mathrm{DAPI}$ bands: $\mathrm{Ce}^{-}$ centromeric; $\mathrm{T}=$ telomeric; $\mathrm{P}=$ proximal $\mathrm{ST}=$ subtelomeric; $\mathbf{4 5 S}$, number of DNAr 18-5.8-26S loci and 5S, number of DNAr 5S loci.).An asterisk indicates new cytotypes and two asterisks new chromosome number for a taxon.

\begin{tabular}{|c|c|c|c|c|c|c|c|c|c|c|}
\hline \multirow{2}{*}{ Taxon } & \multirow{2}{*}{$2 n$} & \multirow{2}{*}{ TL } & \multirow{2}{*}{ TLH } & \multirow{2}{*}{$\mathbf{C}$} & \multirow{2}{*}{$\% \mathrm{Ht}$} & \multirow{2}{*}{$\begin{array}{l}\text { CMA } \\
\text { NOR }\end{array}$} & \multirow{2}{*}{ CMA } & \multicolumn{2}{|c|}{ FISH } & \multirow{2}{*}{$\begin{array}{l}\text { Comparisons with Realini et al } \\
\qquad(2014)\end{array}$} \\
\hline & & & & & & & & $45 \mathrm{~S}$ & $5 S$ & \\
\hline \multicolumn{11}{|l|}{ elata complex } \\
\hline O. elata var. elata & 44 & 96.73 & 24.18 & 2.2 & 2.4 & 1 & $1 \mathrm{~T}, 1 \mathrm{Ce}$ & 1 & 2 & $4 \mathrm{~T}, \mathrm{P}$ in all chrom, $6 \mathrm{P}^{\mathrm{DAPI}}{ }^{+}$ \\
\hline O. elata var. cardiosperma & 44 & 121.6 & 30.4 & 2.77 & 3.47 & 1 & \begin{tabular}{|c|}
1 \\
T,several \\
Ce
\end{tabular} & 2 & 2 & - \\
\hline O. elata var. obovata & $44^{* *}$ & 114.4 & 28.61 & 2.6 & 4.3 & 2 & $1 \mathrm{Ce}$ & 1 & 2 & - \\
\hline O. stenarthra & 44 & 79.03 & 19.75 & 1.79 & 3.25 & 1 & $1 \mathrm{~T}$ & 1 & 2 & - \\
\hline \multicolumn{11}{|l|}{ megapotamica complex } \\
\hline
\end{tabular}




\begin{tabular}{|c|c|c|c|c|c|c|c|c|c|c|}
\hline O. bonaerensis & 44 & 63.19 & 15.8 & 1.43 & 3.9 & 1 & $1 \mathrm{Ce}$ & 1 & 2 & $4 \mathrm{~T}$ \\
\hline $\begin{array}{l}\text { O. megapotamica var. } \\
\text { megapotamica }\end{array}$ & 44 & 93.47 & 23.37 & 2.12 & 4.28 & $2 / 1$ & $1 \mathrm{Ce}$ & 2 & 2 & $2 \mathrm{~T}, \mathrm{P}$ in all chrom \\
\hline $\begin{array}{l}\text { O. megapotamica var. } \\
\text { chadihuensis }\end{array}$ & $44 * *$ & 119.5 & 29.87 & 2.71 & 1.83 & 2 & $1 \mathrm{~T}, 1 \mathrm{Ce}$ & 1 & 2 & - \\
\hline $\begin{array}{l}\text { O. megapotamica var. } \\
\text { salagria }\end{array}$ & $44 * *$ & 117.4 & 29.34 & 2.67 & 3.27 & 1 & $1 \mathrm{Ce}$ & 2 & 2 & - \\
\hline O. penicilligera & 44 & 108.8 & 27.2 & 2.47 & 3.33 & 1 & $\begin{array}{l}\text { Ce all } \\
\text { chrom }\end{array}$ & 1 & 2 & $2 \mathrm{~T}$ \\
\hline \multicolumn{11}{|l|}{ monacantha complex } \\
\hline O. monacantha & $22 *$ & 46.68 & 23.34 & 2.04 & 3.02 & 1 & $1 \mathrm{Ce}$ & 1 & 1 & $2 \mathrm{~T}, \mathrm{P}$ in all chrom \\
\hline \multirow[t]{2}{*}{ O. arechavaletae } & 22 & 64.68 & 32.34 & 2.94 & 5.21 & 1 & $1 \mathrm{Ce}$ & 1 & 1 & $\begin{array}{c}2 \mathrm{~T}, 1 \mathrm{ST}, 1 \text { occupying a large } \\
\text { chrom, } \mathrm{P} \text { in all chrom, } 3 \mathrm{~T} \\
\text { DAPI }+\end{array}$ \\
\hline & $44 *$ & 100.8 & 25.2 & 2.29 & 3.97 & 2 & $2 \mathrm{Ce}$ & 2 & 2 & - \\
\hline
\end{tabular}




\section{Figure captions}

Fig. 1. Distribution map of the populations of Opuntia ser. Armatae studied. Map obtained with DIVA-GIS 2 (Hijmans et al. 2002).

Fig. 2. PCA of Opuntia ser. Armatae using morphological characters. A: Biplot of principal component $1(\mathrm{CP} 1)$ and $2(\mathrm{CP} 2)$; B: Table of autovectors. The meaning of codes is included in Table 1. Opuntia elata complex = squares; megapotamica complex = circles; monacantha complex $=$ triangles.

Fig. 3. Fluorochrome chromosome banding in Opuntia ser. Armatae. A, B: Opuntia monacantha; C, D: Opuntia arechavaletae $(2 \mathrm{n}=22) ; \mathrm{E}, \mathrm{F}:$ Opuntia arechavaletae $(2 \mathrm{n}=22)$; G, H: Opuntia elata var. elata; I, J: Opuntia elata var. cardiosperma; K, L: Opuntia elata var. ovobata. A, C, E, G, I, K, CMA fluorescence; B, D, F, H, J, L, DAPI fluorescence. Arrows indicate $\mathrm{CMA}^{+} / \mathrm{DAPI}^{-} \mathrm{NOR}$ associated bands. $\mathrm{Bar}=5 \mu \mathrm{m}$, all at the same scale.

Fig. 4. Fluorochrome chromosome banding in Opuntia ser. Armatae. A, B: Opuntia stenarthra; C, D: Opuntia megapotamica var. megapotamica; E, F: Opuntia megapotamica var. salagria; G, H:Opuntia megapotamica var. chadihuensis; I, J: Opuntia bonaerensis; K, L:Opuntia penicilligera. A, C, E, G, I, K, M, O, Q, S, U, W, CMA fluorescence; B, D, F, H, J, L, DAPI fluorescence. Arrows indicate $\mathrm{CMA}^{+} / \mathrm{DAPI}^{-} \mathrm{NOR}$ associated bands. $\mathrm{Bar}=5 \mu \mathrm{m}$, all at the same scale.

Fig. 5. FISH of 18S-5.8S-26S and 5S rDNA to metaphase chromosomes in Opuntia ser. Armatae simultaneously detected in all species. A: Opuntia monacantha; B: Opuntia arechavaletae; C: O. arechavaletae; D: Opuntia elata var. elata; E: Opuntia elata var. cardiosperma; F: Opuntia elata var. ovobata; G: Opuntia stenarthra; H: Opuntia megapotamica var. megapotamica; I: Opuntia megapotamica var. salagria; J: Opuntia 
megapotamica var. chadihuensis; K: O. bonaerensis; L: O. penicilligera. Arrows indicate185.8-26S rDNA and asterisks 5S rDNA. Bar $=5 \mu \mathrm{m}$, all at the same scale.

Fig. 6. Idiograms of Opuntia ser. Armatae species. Loci of 18-5.8-26S rDNA and $\mathrm{CMA}^{+} / \mathrm{DAPI}^{-} / \mathrm{NOR}$ associated $=$ black, loci $5 \mathrm{~S} \mathrm{rDNA}=$ red, $\mathrm{CMA}^{+} / \mathrm{DAPI}^{-} / \mathrm{NOR}$ associated $=$ green, bands $\mathrm{CMA}^{+} / \mathrm{DAPI}^{-}=$yellow. $\mathrm{Bar}=2 \mu \mathrm{m}$, all at the same scale.

Fig. 7. PCA of Opuntia ser. Armatae using cytogenetical features. A: Biplot of principal component $1(\mathrm{CP} 1)$ and $2(\mathrm{CP} 2)$; B: Table of autovectors. The meaning of codes is included in Table 1. Opuntia elata complex = squares; megapotamica complex = circles; monacantha complex $=$ triangles.

Fig. 8. Morphological features of Opuntia ser. Armatae species. Opuntia elata var. elata. A: Habit; B: Flowers and flower buds; C: Seed. Opuntia elata var. cardiosperma. D: Seed. Opuntia elata var. obovata. E: Habit; F: Fruits; G: Flower bud. Opuntia stenarthra. H: Habit; I: Fruits; J: Dried and hydrated seeds, respectively. K: Gynoecia of O. anacantha var. retrorsa and O. stenarthra, respectively. Opuntia megapotamica var. chadihuensis. L: Habit; M: Flower bud; N: Longisection of ripe fruit of O. megapotamica var. chadihuensis and var. megapotamica, respectively. 


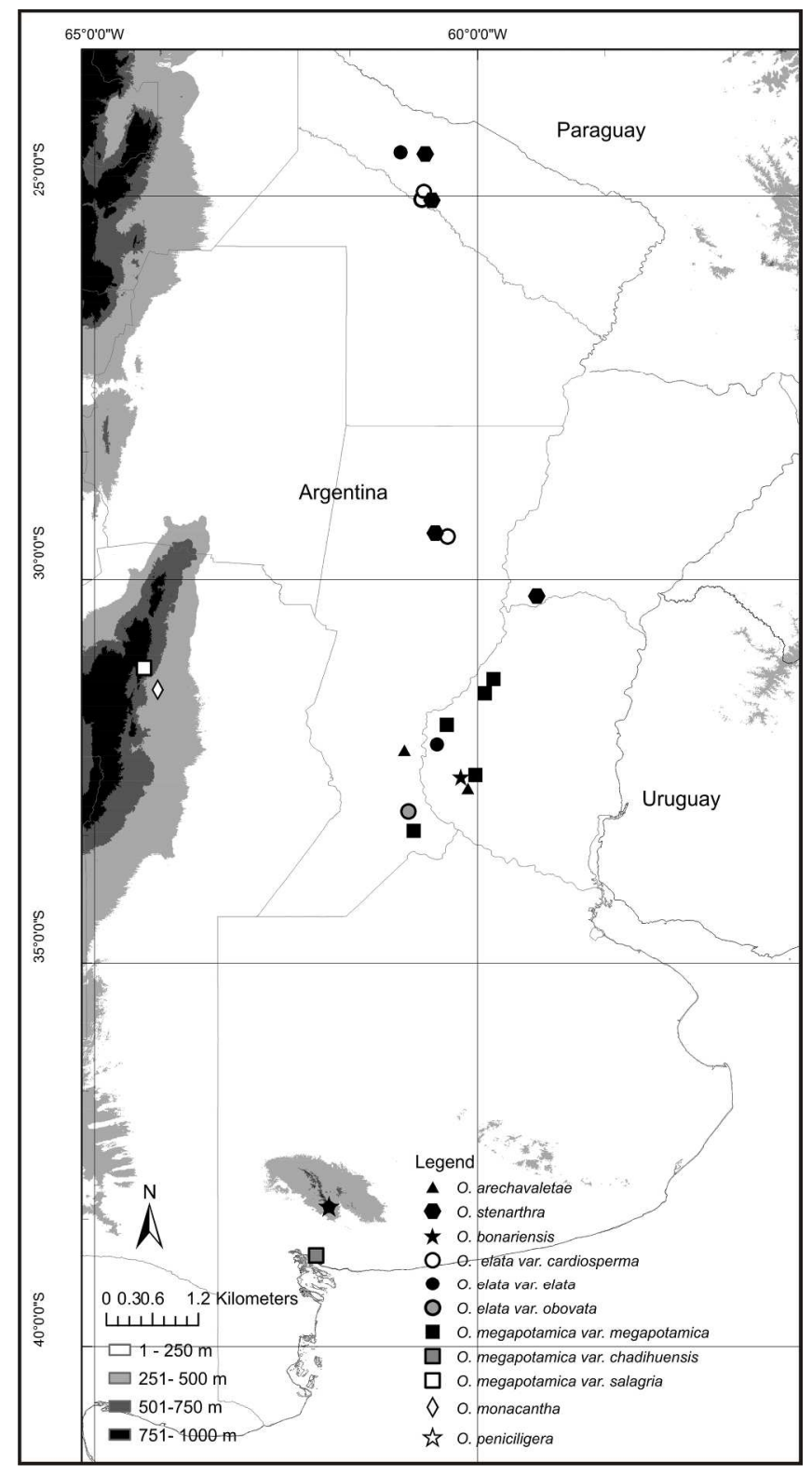

Fig. 1.Distribution map of the populations of Opuntia ser. Armatae studied. Map obtained with DIVA-GIS 2 (Hijmans et al. 2002).

$148 \times 275 \mathrm{~mm}$ ( $300 \times 300$ DPI) 


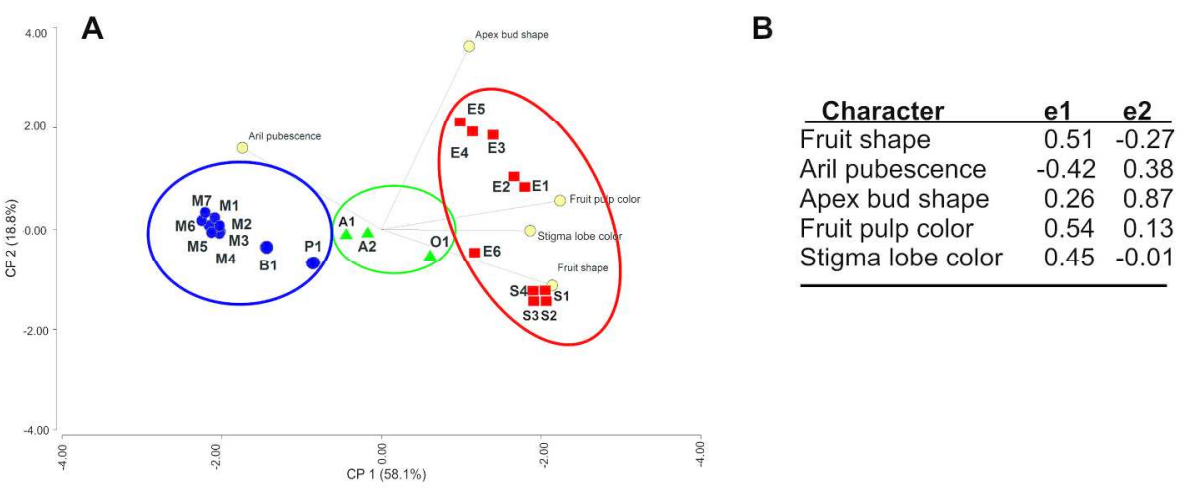

Fig. 2. PCA of Opuntia ser. Armatae using morphological characters. A: Biplot of principal component 1 (CP1) and 2 (CP2); B: Table of autovectors. The meaning of codes is included in Table 1. Opuntia elata complex $=$ squares; megapotamica complex $=$ circles; monacantha complex $=$ triangles .

$209 \times 90 \mathrm{~mm}(300 \times 300 \mathrm{DPI})$ 

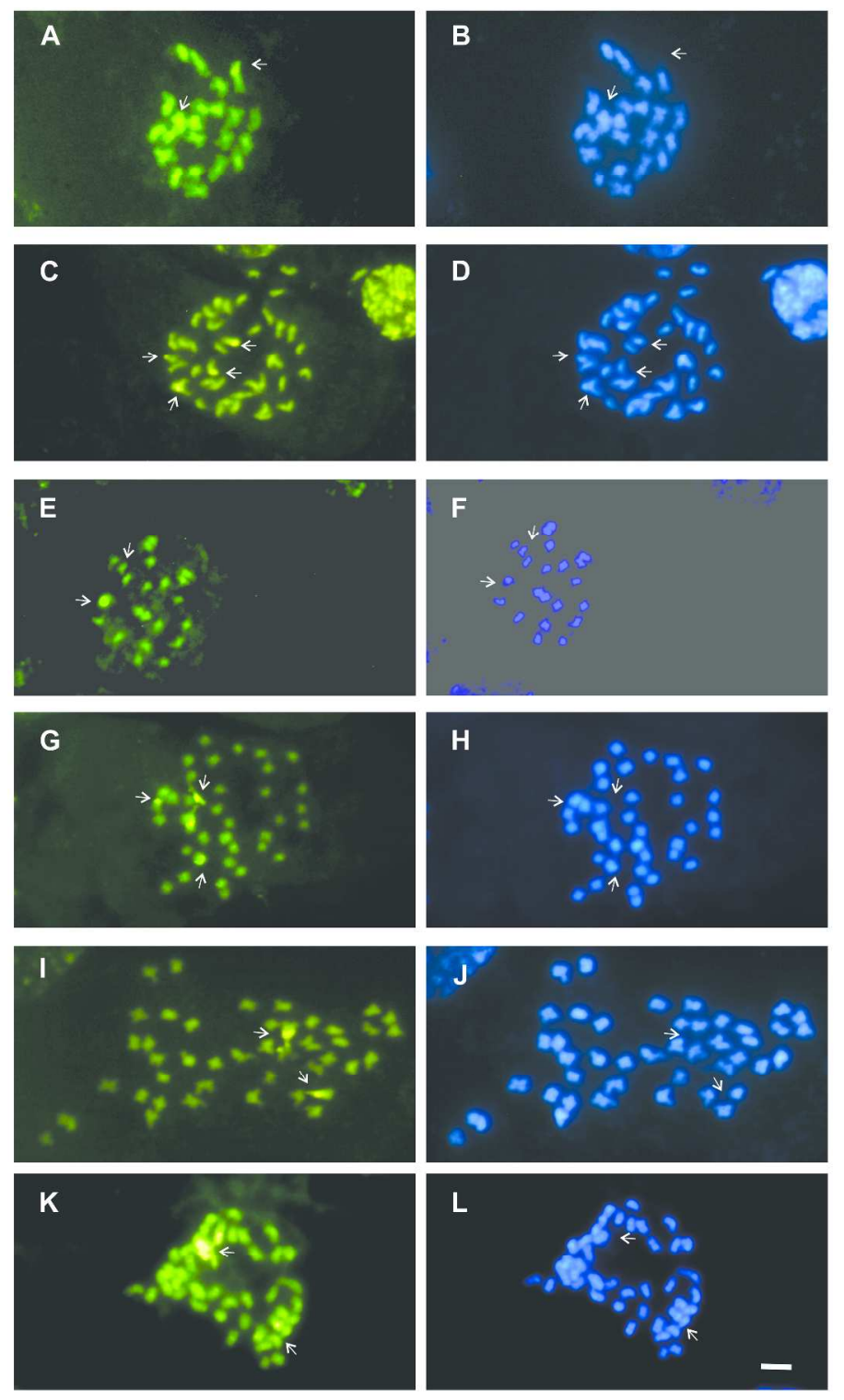

Fig. 3. Fluorochrome chromosome banding in Opuntia ser. Armatae. A, B: Opuntia monacantha; C, D: Opuntia arechavaletae $(2 \mathrm{n}=22) ; \mathrm{E}, \mathrm{F}$ : Opuntia arechavaletae $(2 \mathrm{n}=22) ; \mathrm{G}, \mathrm{H}$ : Opuntia elata var. elata; I, J: Opuntia elata var. cardiosperma; K, L: Opuntia elata var. ovobata. A, C, E, G, I, K, CMA fluorescence; B, $D, F, H, J, L$, DAPI fluorescence. Arrows indicate CMA+/DAPI- NOR associated bands. Bar $=5 \mu \mathrm{m}$, all at the same scale.

$263 \times 441 \mathrm{~mm}(300 \times 300 \mathrm{DPI})$ 

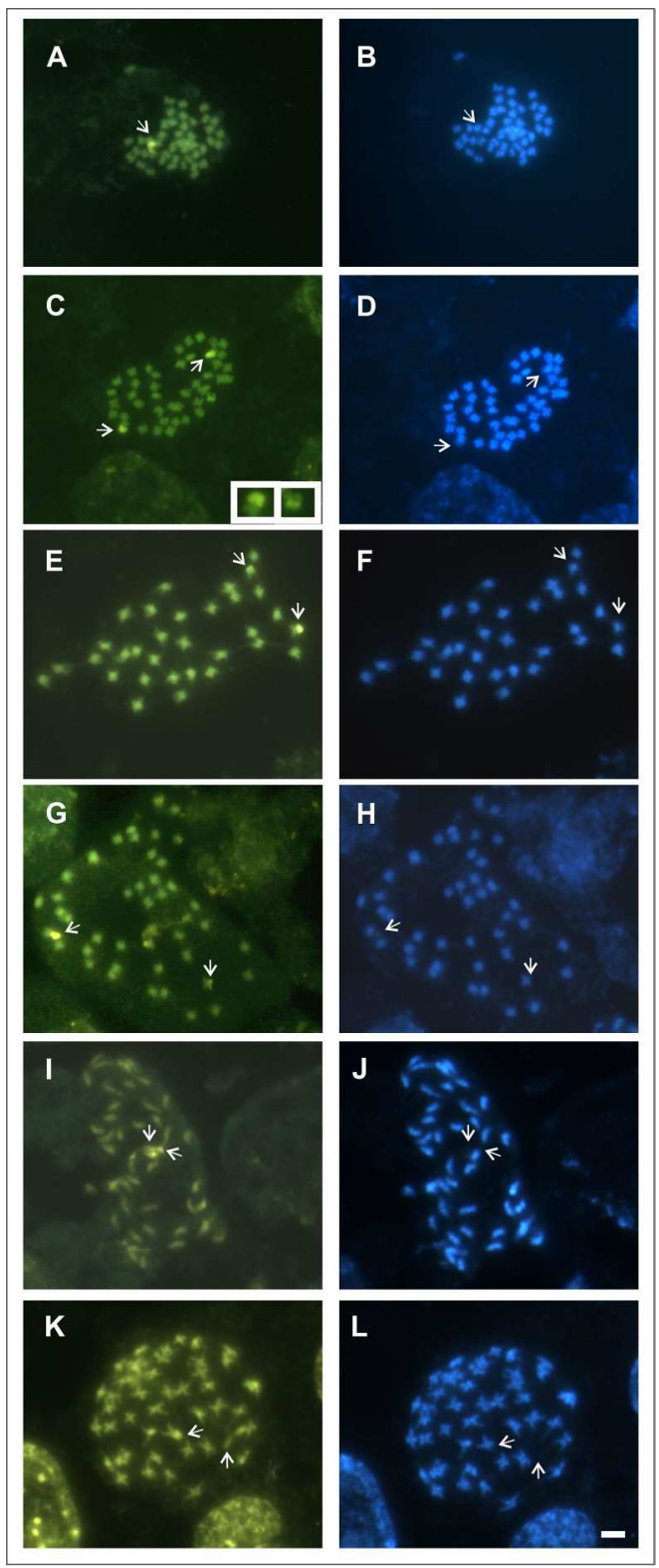

Fig. 4. Fluorochrome chromosome banding in Opuntia ser. Armatae. A, B: Opuntia stenarthra; C, D: Opuntia megapotamica var. megapotamica; E, F: Opuntia megapotamica var. salagria; G, H:Opuntia megapotamica var. chadihuensis; I, J: Opuntia bonaerensis; K, L:Opuntia penicilligera. A, C, E, G, I, K, M, O, Q, S, U, W, CMA fluorescence; $B, D, F, H, J, L$, DAPI fluorescence. Arrows indicate CMA+/DAPI- NOR associated bands. Bar $=5 \mu \mathrm{m}$, all at the same scale.

$98 \times 235 \mathrm{~mm}(300 \times 300 \mathrm{DPI})$ 


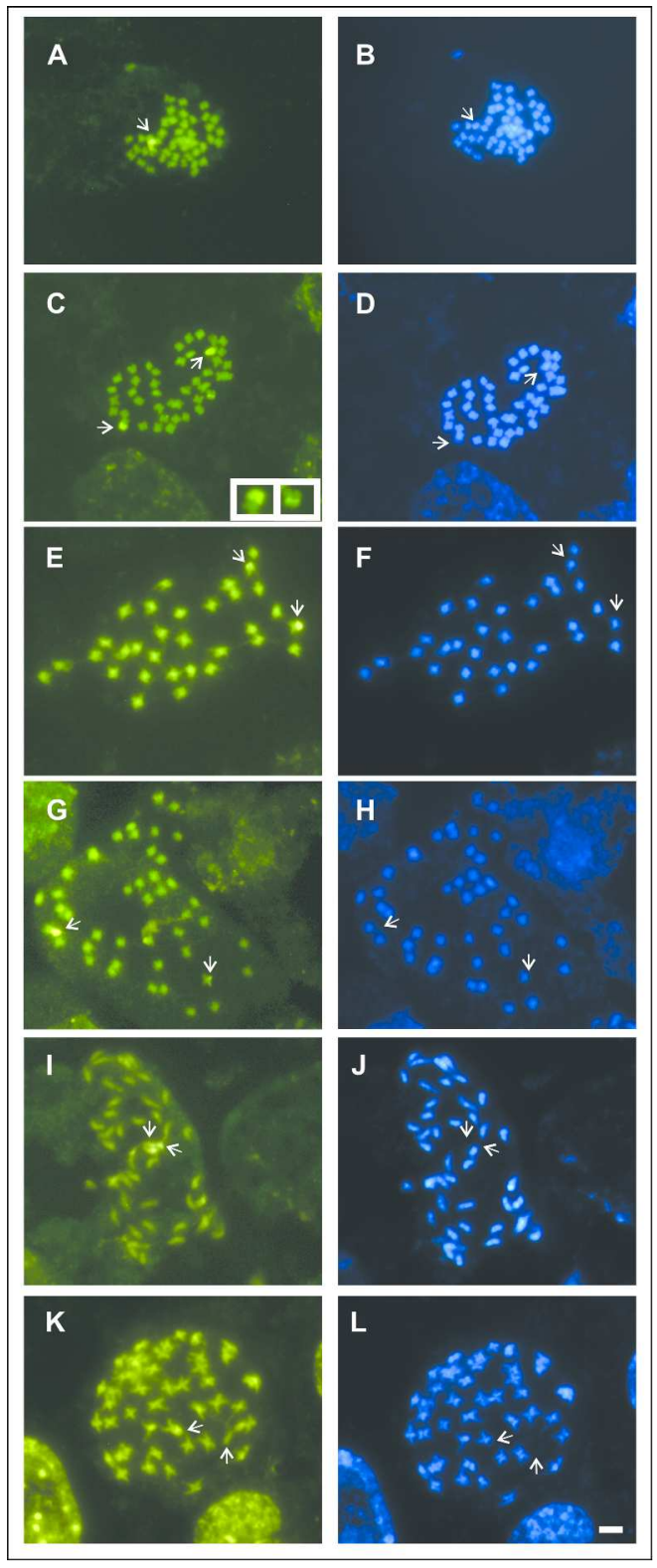

$235 \times 566 \mathrm{~mm}(300 \times 300 \mathrm{DPI})$ 

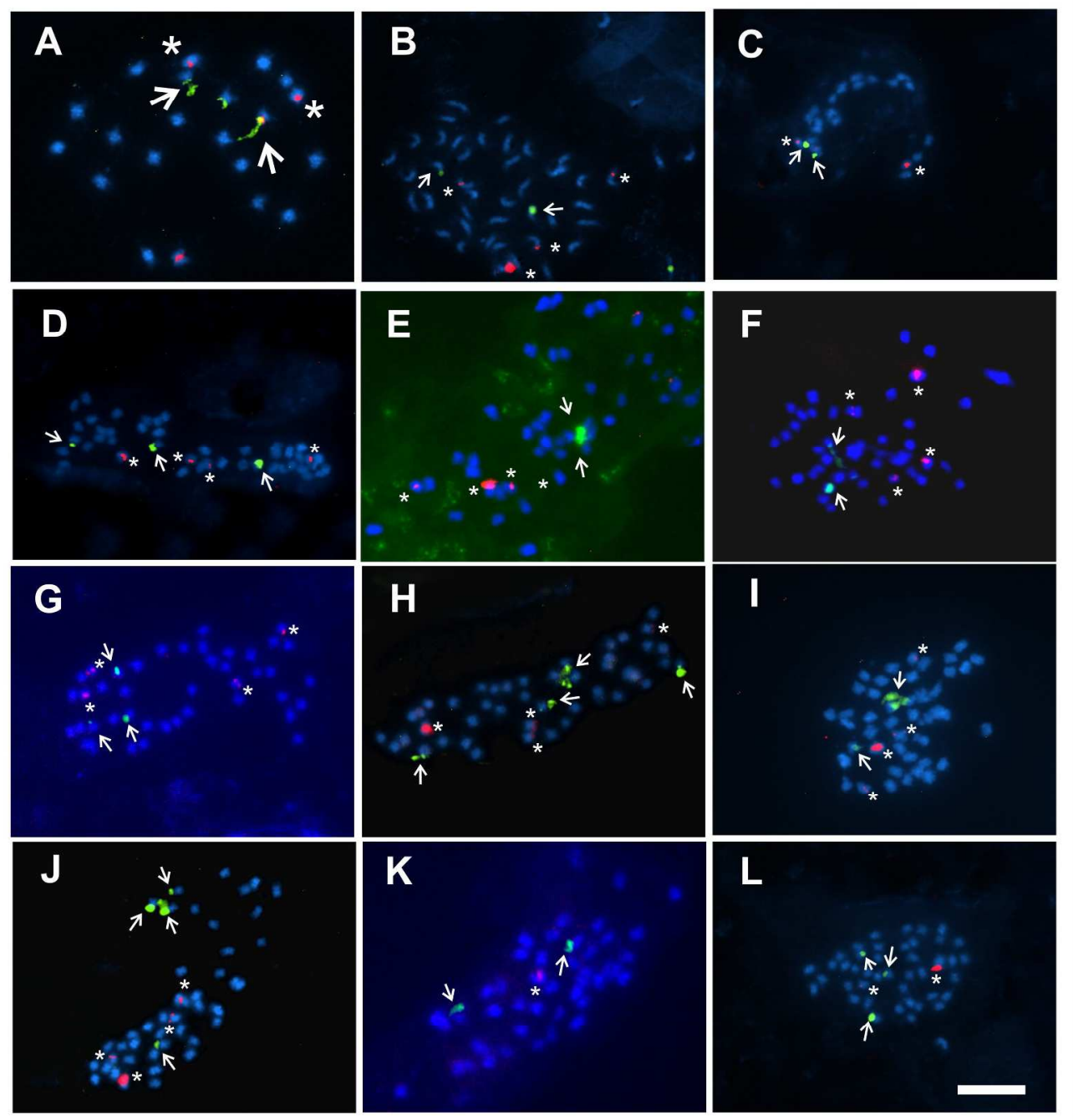

Fig. 5. FISH of 18S-5.8S-26S and 5S rDNA to metaphase chromosomes in Opuntia ser. Armatae simultaneously detected in all species. A: Opuntia monacantha; B: Opuntia arechavaletae; C: O. arechavaletae; D: Opuntia elata var. elata; E: Opuntia elata var. cardiosperma; F: Opuntia elata var. ovobata; G: Opuntia stenarthra; H: Opuntia megapotamica var. megapotamica; I: Opuntia megapotamica var. salagria; J: Opuntia megapotamica var. chadihuensis; K: O. bonaerensis; L: O. penicilligera. Arrows indicate18-5.8-26S rDNA and asterisks 5S rDNA. Bar $=5 \mu \mathrm{m}$, all at the same scale.

$234 \times 249 \mathrm{~mm}(300 \times 300 \mathrm{DPI})$ 


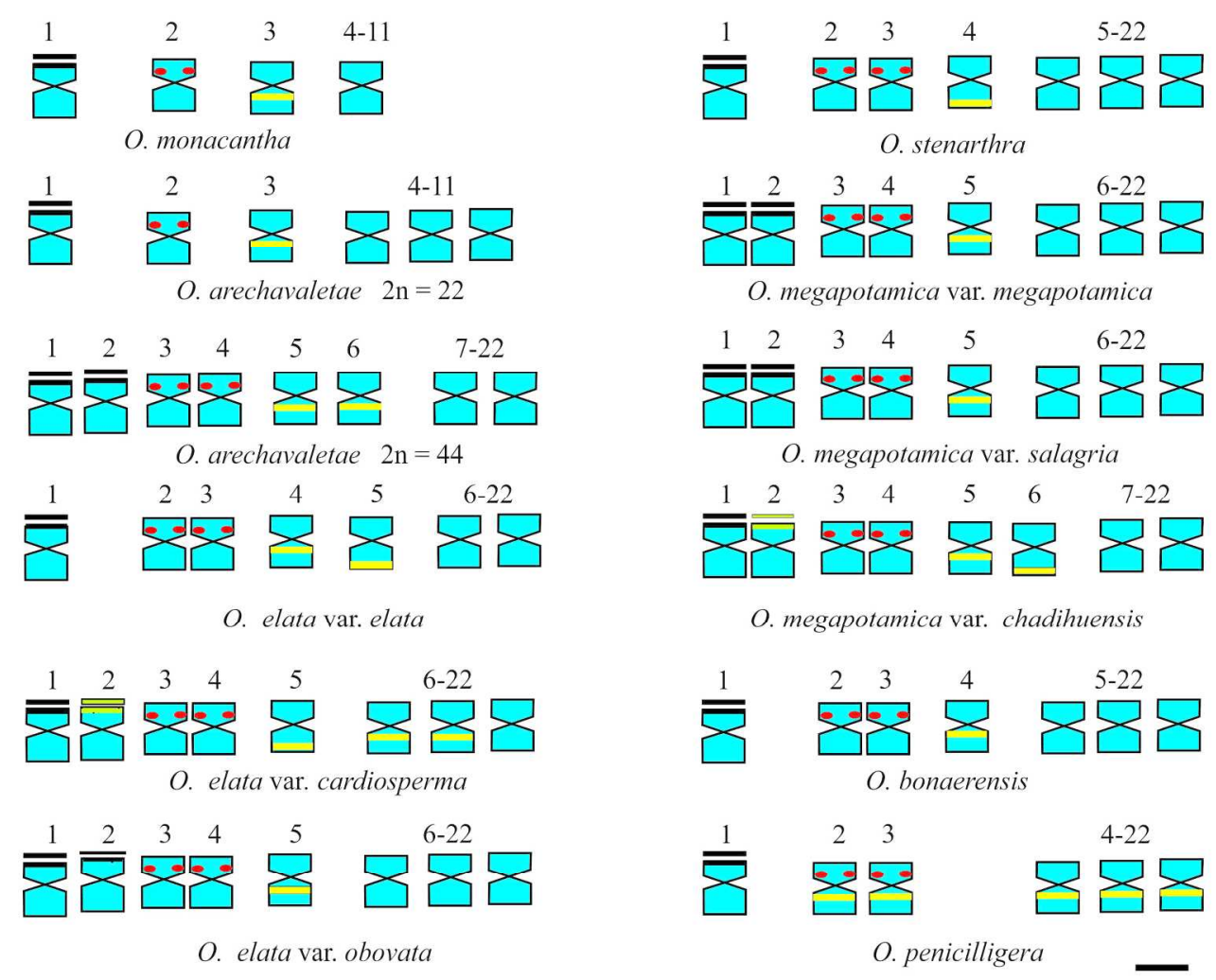

Fig. 6. Idiograms of Opuntia ser. Armatae species. Loci of 18-5.8-26S rDNA and CMA+/DAPI-/NOR associated $=$ black, loci $5 \mathrm{~S}$ rDNA $=$ red, CMA+/DAPI-/NOR associated $=$ green, bands CMA+/DAPI- $=$ yellow . Bar $=2 \mu \mathrm{m}$, all at the same scale. $192 \times 156 \mathrm{~mm}(300 \times 300$ DPI) 


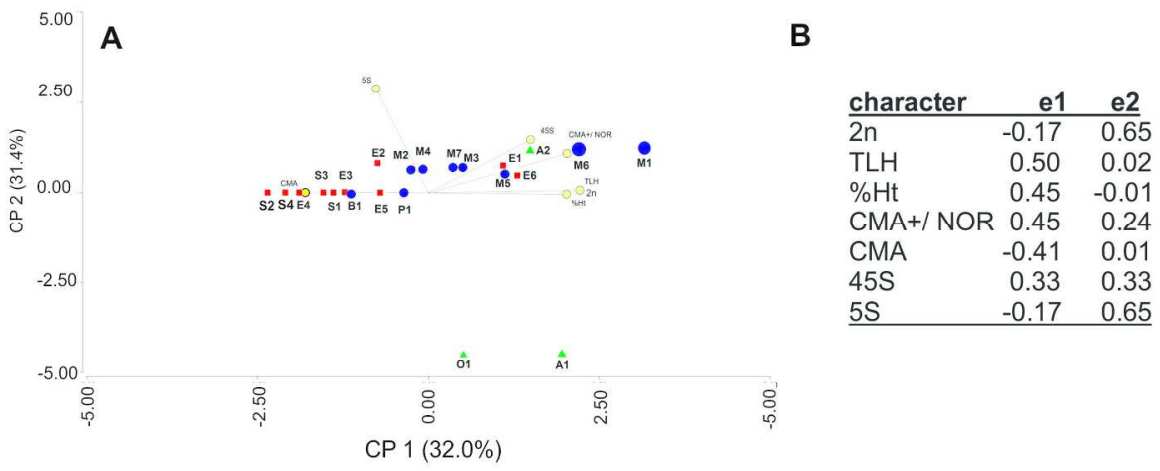

Fig. 7. PCA of Opuntia ser. Armatae using cytogenetical features. A: Biplot of principal component 1 (CP1) and 2 (CP2); B: Table of autovectors. The meaning of codes is included in Table 1. Opuntia elata complex = squares; megapotamica complex = circles; monacantha complex $=$ triangles.

$211 \times 88 \mathrm{~mm}(300 \times 300 \mathrm{DPI})$ 

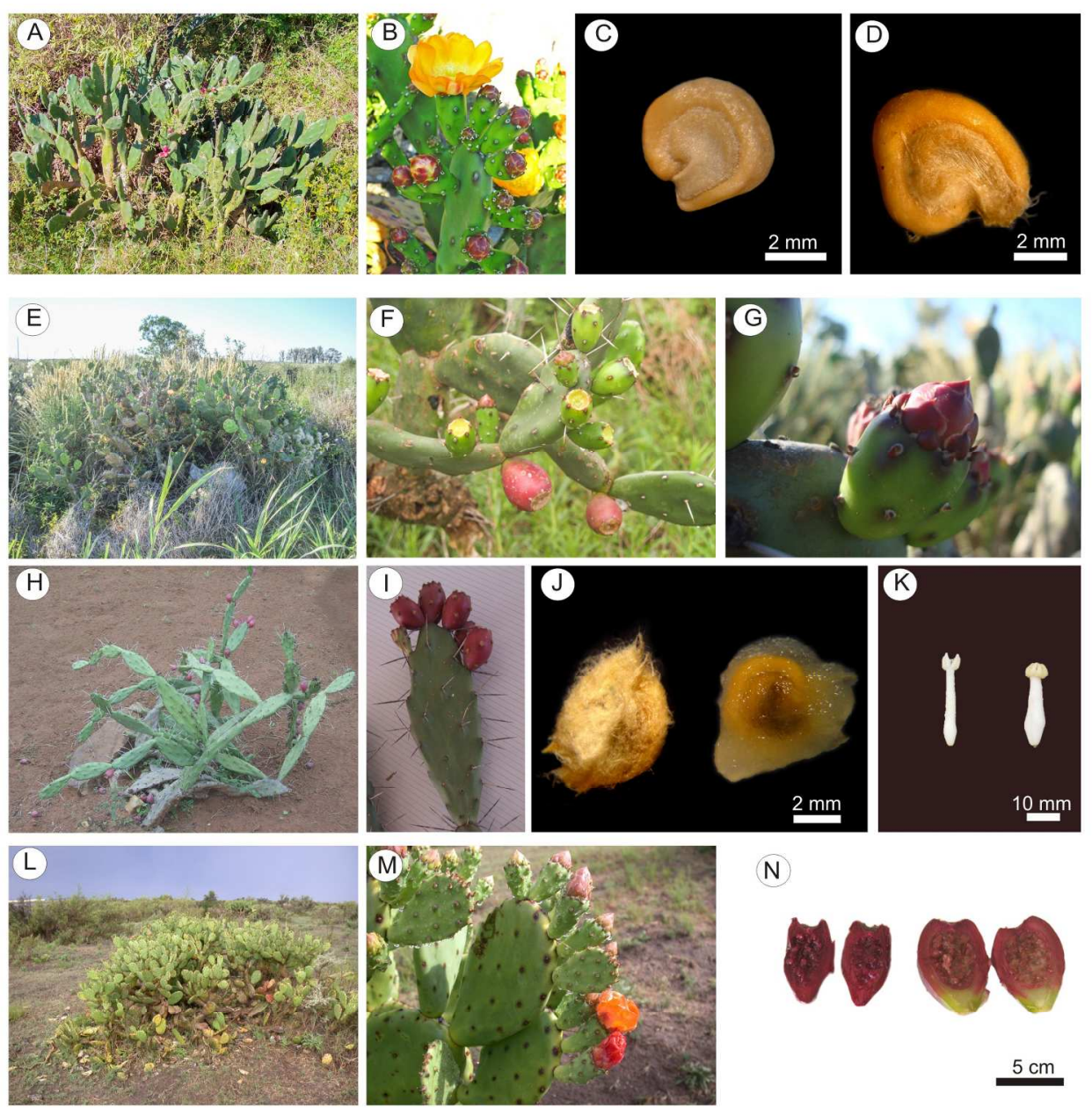

N

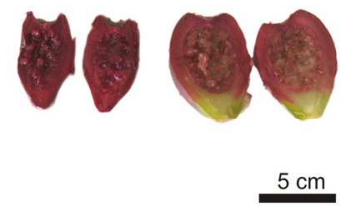

Fig. 8. Morphological features of Opuntia ser. Armatae species. Opuntia elata var. elata. A: Habit; B: Flowers and flower buds; C: Seed. Opuntia elata var. cardiosperma. D: Seed. Opuntia elata var. obovata. E: Habit; F: Fruits; G: Flower bud. Opuntia stenarthra. H: Habit; I: Fruits; J: Dried and hydrated seeds, respectively. $\mathrm{K}$ : Gynoecia of $\mathrm{O}$. anacantha var. retrorsa and $\mathrm{O}$. stenarthra, respectively. Opuntia megapotamica var. chadihuensis. L: Habit; M: Flower bud; $\mathrm{N}$ : Longisection of ripe fruit of $\mathrm{O}$. megapotamica var. chadihuensis and var. megapotamica, respectively.

$204 \times 199 \mathrm{~mm}(300 \times 300$ DPI $)$ 
Appendix A1. Additional representative specimens studied.

Opuntia arechavaletae. SOUTH AMERICA. ARGENTINA. Buenos Aires. 15 km N de Magdalena, ruta 11, 27 April 2004, Villamil 10312 (BBB). Misiones. Piray, 25 January 1952, Castellanos 19411 (BA). URUGUAY. Maldonado. Cerro Pelado, 26 December 1946, Castellanos 81561 (LIL).

Opuntia bonaerensis. ARGENTINA. Buenos Aires. Bahía Blanca, ruta 33 hacia Tornquist, 8 June 1998, Villamil 8826 (BBB). Bahía Blanca, 25 May 1999, Villamil 9006 (BBB). Campana, 8 December 1920, Castellanos s.n. (BA 17378). Tandil, cerro Los Barrientos, 28 December 1941, R. Spegazzini s.n. (BA 63450).

Opuntia elata var. elata. ARGENTINA. Buenos Aires. Isla Martín García, 20 December 1946, Palacios 66 (LIL). Catamarca. Paclín, 10 km from La Viña over Cuesta del Totoral, towards La Merced, ruta 38, Leuenberger et al. 4337 (CORD). Chaco. El Colchón, 26 November 2004, Martínez 97 (CORD). Corrientes. Esquina, Estancia La Blanca, 14 March 1975, Krapovickas et al. 27729 (CTES). Mburucuyá, Estancia Santa María, 22 July 1956, Pedersen 3935 (C, P). Saladas, Río Santa Lucía, Paso Naranjito, 30 March 1974, Krapovickas et al. 24570 (CTES). Entre Ríos. Colón, 8 December 1976, Velazco 1977 (BA). Concepción del Uruguay, cerca del Parque Unzué, 19 February 1965, Burkart 25762 (SI). Diamante, December 1960, Burkart 22238 (SI). Gualeguaychú, 3 September 1973, Erb s.n. (LIL 585070). Formosa. Vaca Perdida, 20 March 1986, Arenas 3230 (BACP). La Soledad, 13 October 1982, Molina 596 (BAB). La Rinconada, 20 December 1996, Scarpa 33 (BACP). Ing. Juárez, February 1983, Maranta \& Arenas 350 (BA). Estancia Nacif, 20 km N de Ing. Juárez, ruta 83, 2354’S/61º51'W, 24 February 1983, Arenas 2296 (BACP). Las Lomitas, 2449’S/60³6’W, 1988, Sturzenegger s.n. 
(BACP 3006). 1 km N de Posta Cambio Salazar, 24¹2’S/60¹0’W, 10 November 1994, Fortunato et al. 4451 (BAB). El Quebracho, 233'S/62º'W, 5 December 1983, Maranta 453 (BCAP). Salta. Misión La Paz, 22²8’S/62²2’W, 15 February 1982, Arenas 2119 (BACP). Los Blancos, 21 January 1983, Maranta \& Arenas 321 (BACP). 2 km E de Misión La Paz, 6 January 2003, Scarpa 565 (SI, CTES). Santa Fe. 10 Km E de Tostado, ruta 98, 24 March 1980, Williams et al. 922 (BA, CTES). Tucumán. Tucumán, Río Salí, en isla del río, 19 January 1924, Venturi 2940 (LIL). BOLIVIA. Santa Cruz. Around highway and railroad bridges over Río Seco on N side of settlement of Río Seco, along new highway from Santa Cruz to Abapó, 18³9’S/63ํำ'W, 24 May 1998, Nee \& Bohs 49472 (NY, CORD!). BRASIL. Rio Grande do Sul. Quaraí, Serra Jaraô, 27 November 1979, Pedersen 12560 (CTES). PARAGUAY. Boquerón. Cercanías de Filadelfia, June 1986, Mereles 1239 (FCQ). Km 412, ruta 9, Carlos A. López, 2 km del cruce a Loma Plata, picada 17, 31 October 1989, Peña \& Quintana 423 (PY). Parque Valle Natural, 8 km de Colonia Neuland, $22^{\circ} 36^{\prime}$ S $/ 60^{\circ} 5^{\prime}$ W, 13 March 2005, Fortunato et al. 8780 (BAB).

Presidente Hayes. Km 18 ruta 12 hacia Fortín Martínez, 12 November 1985, Brunner 1345 (PY). Cercanías de Campo León, 30 October 1992, Mereles \& Degen 4963 (FCQ).

URUGUAY. Montevideo. Peñarol, March 1924, Herter 85334 (LIL).

Opuntia elata var. cardiosperma. ARGENTINA. Corrientes. Ituzaingó, Ruta 34, $12 \mathrm{~km}$ do Destacamento Policial Santo Tomás en direção a ruta $12,27.5666^{\circ} \mathrm{S} / 55.9912^{\circ} \mathrm{W}$, 18 January 2007, Paula-Souza 7403 (ESA, CTES). Paso de la Patria, 4 Km E de esta última, 20 February 1969, Krapovickas \& Cristóbal 14939 (CTES, LIL). Formosa. Reserva Ecológica El Bagual, San Francisco de Laishi, 22 July 1999, Di Giacomo 412 (BAB, CTES). El Colorado, October 71, Insfran 895 (CTES). Santa Fe. Límite con 
Santiago del Estero, 10 October 1943, Castellanos s.n. (BA 47329). BOLIVIA. Santa

Cruz. Along road to San Joaquin, just E of La Mora, $18^{\circ} 27^{\prime} \mathrm{S} / 63^{\circ} 12^{\prime} \mathrm{W}, 24$ January 1998 , Nee 48142 (NY, CTES!). PARAGUAY. Boquerón. Fortín Avalos Sánchez, 30 October 1985, Mereles 665 (FCQ). Campo Loro, 8 April 1987, Schmeda 870 (FCQ). Itapuá.

Encarnación, 7 October 1987, Basualdo 1518 (FCQ). Paraguarí. Cerro Mbatoví, $25^{\circ} 25^{\prime} \mathrm{S} / 57^{\circ} 07^{\prime} \mathrm{W}, 2$ July 1988, Zardini 5468 (MO, FCQ). Valle Apu'a, Colonia Achotei, Estancia Lago Ypoa, 2559'11.4'’S/57²6'31'’W, 9 November 2000, Mereles et al. 8255 (FCQ). Presidente Hayes. Cerrito, cercanías del río Verde, 25 May 1987, Zardini et al. $2646(\mathrm{MO}, \mathrm{FCQ})$

Opuntia elata var. obovata. ARGENTINA. Buenos Aires. Isla Martín García, 18 June 1926, Molfino \& Clos 484 (BAB). Tandil Parque, 12 December 1948, Meyer 14395 (LIL). Córdoba. Ruta 13, entre Fortín y Alicia, 3157'44.8"S/62²0'15.3"W, 19 November 2014, Oakley et al. 154 (CORD). Entre Ríos. Gualeguaychú, Parque Unzué, 18 April 1965, Burkart 25763 (SI). Santa Fe. Ruta 33 y vías del Ferrocarril, entre Pérez y Zavalla, 2004, Villamil 10167 (BBB). URUGUAY. Montevideo. La Colorada, al fin del camino Sanguinetti, 9 December 1947, Castellanos s.n. (LIL 15807).

Opuntia megapotamica var. megapotamica. ARGENTINA. Buenos Aires. Tigre, Arroyo Las Conchas (Maschwitz-Benavídez), 4 December 1954, Mazzucconi 687 (BAB). Entre Ríos. Punta Caballo, 12 December 1974, Burkart 30962 (SI). Ruta 12, km 415, 26 October 1961, Pedersen 6288 (SI). Ruta 14, entre Jubileo y Villa Clara, ca. 1 km NE Arroyo Sandoval, 22 February 1996, Leuenberger \& Arroyo 4498 (SI). Santa Fe. Pavón Arriba, ruta 178, 14 June 1999, Villamil 9016 (BBB). Ruta 6, Río Salado, Pensiero et al. 3973 (SF). 
Opuntia megapotamica var. chadihuensis. ARGENTINA. Buenos Aires. Las Piletas, 22 January 1947, Rossi \& Bachmann 862 (LIL).

Opuntia megapotamica var. salagria. ARGENTINA. Buenos Aires. Bahía Blanca, 19 July 1998, Villamil 8830 (BBB). Córdoba. Valle de los Reartes, February 1924, Castellanos 24-883 (BA). Capilla del Monte, Cerro Uritorco, 14 April 1915, Hosseus 127 (CORD). Dique San Roque, 21 July 1924, Castellanos 24-1344 (BA). Pedanía La Paz, Quebrada del Cristal de Roca, 29 January 1939, Castellanos s.n. (BA 30541). Mar Chiquita, 6 November 1952, Castellanos s.n. (BA 55726). La Pampa. Riglos, 29 May 1999, Villamil 9010 (BBB). Macachín, 29 May 1999, Villamil 9011 (BBB). Santa Fe. Villa Minetti, 20 March 1940, Ragonese s.n. (BA 33033). Rosario, en los barrancos, 4 July 1926, Castellanos 26-1849 (BA).

Opuntia monacantha. BRASIL. Rio de Janeiro. Restinga de recreio dos Bandeirantes, 20 April 1961, Castellanos 23151 (LIL). Praia de Grumari, 22 February 1960, Angeli 69 (LIL). Rio Grande do Sul. Alegrete, ca. 1 km N de la ciudad, 7 October 1999, Kiesling 9319 (SI).

Opuntia penicilligera. ARGENTINA. Buenos Aires. Carmen de Patagones, November 1972, Narosky \& Izurieta 01 (LP). Sierra de la Ventana, Estancia Funke, 14 November 1943, Cabrera 8126 (LP). La Pampa. Parque Nacional Lihuel Calel, 3 March 1996, Kiesling 8732 (SI).

Opuntia stenarthra. ARGENTINA. Corrientes. Molina Punta, 26 December 1970, Krapovickas \& Cristóbal 17292 (CTES). Ruta 12 y Arroyo Riachuelo, 10 January 1976, Schinini 12440 (CTES). Estancia La Yela, 10 February1984, Pedersen 13657 (CTES). 
Esquina, 4 km S de ruta 126, camino de Tres Bocas a Paso Yunque, 13 March 1975, Krapovickas et al. 27668 (CTES). Arroyo Saturno, 14 March 1975, Krapovickas et al. 27675 (CTES). 4 km E de Paso de la Patria, 20 February 1969, Krapovickas \& Cristóbal 14939 (CTES). 10 Km E de San Cayetano, 8 March 1972, Krapovickas et al. 21834 (CTES). 18 km SE de San Luis del Palmar, 2 November 1979, Schinini 19454 (CTES). Formosa. Reserva Ecológica El Bagual, San Francisco de Laishi, 22 July 1999, Di Giacomo 413 (CTES). Ruta 81, 2 km NW de Bazán, 11 December 1979, Schinini 19596 (CTES). PARAGUAY. Ñeembucú. Estancia Redondo, 26³4'3'’S/58 5' 15','W, 25 January 2005, De Egea et al. 712 (FCQ, BM). Presidente Hayes. Fn. E. Ayala (Nanawa), $23^{\circ} 24^{\prime} \mathrm{S} / 59^{\circ} 45^{\prime} \mathrm{W}$, January 1981, Arenas s.n. (BACP 2379). Ruta Ñ, a 5 km de la R. Traschaco, $24^{\circ} 17^{\prime} 46.5^{\prime}$ 'S $/ 58^{\circ} 16^{\prime} 18.5^{\prime}$ 'W, 16 December 2011 , Vera et al. 3250 (FCQ). 
Appendix A2. Character coding of morphological and cytogenetical traits used for the Principal Component Analysis.

\begin{tabular}{|l|c|c|}
\hline Character & state & code \\
\hline Fruit shape & obconical & 0 \\
\hline & obpyriform & 1 \\
\hline & obovate & 2 \\
\hline Aril pubescence & clavate & 1 \\
\hline & pubescent & 0 \\
\hline Apex bud shape & glabrous & 1 \\
\hline & acute & 0 \\
\hline & flat & 1 \\
\hline Stigma lobe color & obtuse & 2 \\
\hline & green & 0 \\
\hline Ripe fruit pulp color & white & 1 \\
\hline & red-wine & 0 \\
\hline Number of DNAr $5 S^{10 c i}$ & colored & \\
\hline & greenish & 1 \\
\hline Number of DNAr 18-5.8-26S loci & one pair & 1 \\
\hline & two pairs & 2 \\
\hline Number of CMA ${ }^{+} / \mathrm{DAPI}{ }^{-}$NOR bands & one pair & 1 \\
\hline & two pairs & 2 \\
\hline Position of CMA ${ }^{+} / \mathrm{DAPI}{ }^{-}$bands & one pair & 1 \\
\hline & two pairs & 2 \\
\hline & centromeric & 1 \\
\hline & telomeric & 2 \\
\hline & centromeric & 0 \\
\hline & and telomeric & \\
\hline
\end{tabular}


Appendix A3. Cytogenetical and morphological characters used in PCA. 2n, chromosome number; TLH, mean total haploid chromosome length; \%Ht, heterochromatin amount expressed as percentage of the karyotype length; $\mathbf{C}$, mean chromosome length; $\mathbf{C M A}^{+} / \mathbf{N O R}$, number of chromosome pairs with $\mathrm{CMA}^{+} / \mathrm{DAPI}^{-} \mathrm{NOR}$ associated bands; CMA, position of $\mathrm{CMA}^{+} / \mathrm{DAPI}^{-}$bands; 45S, number of DNAr 18-5.8-26S loci and $\mathbf{5 S}$, number of DNAr 5S loci. See Appendix B for character coding.

\begin{tabular}{|c|c|c|c|c|c|c|c|c|c|c|c|c|c|}
\hline \multirow[b]{2}{*}{ Taxon } & \multicolumn{7}{|c|}{ Cytogenetic characters } & \multicolumn{6}{|c|}{ Morphological characters } \\
\hline & $2 n$ & TLH & $\% \mathrm{Ht}$ & $\begin{array}{l}\text { CMA }^{+} / \\
\text {NOR }\end{array}$ & CMA & $45 S$ & $5 \mathrm{~S}$ & $\begin{array}{l}\text { Fruit } \\
\text { shape }\end{array}$ & \begin{tabular}{|c|} 
Aril \\
pubes \\
cence \\
\end{tabular} & $\begin{array}{c}\text { Apex } \\
\text { bud } \\
\text { shape }\end{array}$ & $\begin{array}{l}\text { Fruit } \\
\text { pulp } \\
\text { color }\end{array}$ & $\begin{array}{l}\text { Stigma } \\
\text { lobe } \\
\text { color }\end{array}$ & Code \\
\hline \multicolumn{14}{|l|}{ elata complex } \\
\hline $\begin{array}{l}\text { O. elata var. } \\
\text { elata }\end{array}$ & 44 & 28.76 & 2.79 & 1 & 2 & 1 & 2 & 1 & 1 & 1 & 1 & 1 & E3 \\
\hline $\begin{array}{l}\text { O. elata var. } \\
\text { elata }\end{array}$ & 44 & 18.4 & 1.54 & 1 & 1 & 1 & 2 & 1 & 1 & 1 & 1 & 1 & E4 \\
\hline $\begin{array}{l}\text { O. elata var. } \\
\text { elata }\end{array}$ & 44 & 25.4 & 2.87 & 1 & 1 & 1 & 2 & 1 & 1 & 1 & 1 & 1 & E5 \\
\hline $\begin{array}{l}\text { O. elata var. } \\
\text { cardiosperma }\end{array}$ & 44 & 31.52 & 4.3 & 1 & 1 & 2 & 2 & 2 & 0 & 1 & 1 & 0 & E1 \\
\hline $\begin{array}{l}\text { O. elata var. } \\
\text { cardiosperma }\end{array}$ & 44 & 29.28 & 2.59 & 1 & 2 & 2 & 2 & 2 & 0 & 1 & 1 & 0 & E2 \\
\hline $\begin{array}{l}\text { O. elata var. } \\
\text { obovata }\end{array}$ & 44 & 28.61 & 4.3 & 2 & 1 & 1 & 2 & 2 & 1 & 0 & 1 & 1 & E6 \\
\hline O. stenarthra & 44 & 19.03 & 4.14 & 1 & 2 & 1 & 2 & 2 & 0 & 0 & 1 & 1 & S1 \\
\hline O. stenarthra & 44 & 15.86 & 2.91 & 1 & 2 & 1 & 2 & 2 & 0 & 0 & 1 & 1 & S2 \\
\hline O. stenarthra & 44 & 26.61 & 2.85 & 1 & 2 & 1 & 2 & 2 & 0 & 0 & 1 & 1 & S3 \\
\hline O. stenarthra & 44 & 17.53 & 3.1 & 1 & 2 & 1 & 2 & 2 & 0 & 0 & 1 & 1 & S4 \\
\hline
\end{tabular}




\begin{tabular}{|c|c|c|c|c|c|c|c|c|c|c|c|c|c|}
\hline O. bonaerensis & 44 & 15.8 & 3.9 & 1 & 1 & 1 & 2 & 1 & 1 & 0 & 0 & 0 & B1 \\
\hline $\begin{array}{c}O . \\
\text { megapotamica } \\
\text { var. } \\
\text { megapotamica }\end{array}$ & 44 & 36.17 & 5.78 & 2 & 1 & 2 & 2 & 0 & 1 & 0 & 0 & 0 & M1 \\
\hline $\begin{array}{c}\text { O. } \\
\text { megapotamica } \\
\text { var. } \\
\text { megapotamica }\end{array}$ & 44 & 20.17 & 3.49 & 1 & 1 & 2 & 2 & 0 & 1 & 0 & 0 & 0 & M2 \\
\hline $\begin{array}{c}\text { O. } \\
\text { megapotamica } \\
\text { var. } \\
\text { megapotamica }\end{array}$ & 44 & 28.33 & 3.43 & 1 & 1 & 2 & 2 & 0 & 1 & 0 & 0 & 0 & M3 \\
\hline $\begin{array}{c}\text { O. } \\
\text { megapotamica } \\
\text { var. } \\
\text { megapotamica }\end{array}$ & 44 & 25.17 & 2.83 & 1 & 1 & 2 & 2 & 0 & 1 & 0 & 0 & 0 & M4 \\
\hline $\begin{array}{c}\text { O. } \\
\text { megapotamica } \\
\text { var. } \\
\text { megapotamica }\end{array}$ & 44 & 25.01 & 5.87 & 2 & 1 & 2 & 2 & 0 & 1 & 0 & 0 & 0 & M6 \\
\hline $\begin{array}{c}\text { O. } \\
\text { megapotamica } \\
\text { var. } \\
\text { chadihuensis }\end{array}$ & 44 & 29.87 & 1.83 & 2 & 0 & 1 & 2 & 0 & 1 & 0 & 0 & 0 & M5 \\
\hline $\begin{array}{c}O . \\
\text { megapotamica } \\
\text { var. salagria }\end{array}$ & 44 & 29.34 & 3.27 & 1 & 1 & 2 & 2 & 0 & 1 & 0 & 0 & 0 & M7 \\
\hline O. penicilligera & 44 & 27.2 & 3.33 & 1 & 1 & 1 & 2 & 2 & 1 & 0 & 0 & 0 & P1 \\
\hline
\end{tabular}




\begin{tabular}{|c|c|c|c|c|c|c|c|c|c|c|c|c|c|}
\hline \multicolumn{14}{|c|}{ monacantha complex } \\
\hline $\begin{array}{c}O . \\
\text { arechavaletae }\end{array}$ & 22 & 32.34 & 5.21 & 1 & 1 & 1 & 1 & 1 & 1 & 0 & 1 & 0 & A1 \\
\hline $\begin{array}{c}O . \\
\text { arechavaletae }\end{array}$ & 44 & 25.2 & 3.97 & 2 & 1 & 2 & 2 & 1 & 1 & 0 & 1 & 0 & A2 \\
\hline O. monacantha & 22 & 23.34 & 3.02 & 1 & 1 & 1 & 1 & 2 & 1 & 0 & 1 & 1 & $\mathrm{O} 1$ \\
\hline
\end{tabular}

